\title{
Chapter 5 \\ Life in the Countries of Origin, Departure and Travel Towards Europe
}

I was living but not really living, I had no taste of anything. I had no life.

(Sandra, Germany)

We should help these people to create a vocabulary, their vocabulary. They have never narrated themselves.

(Valentina, social worker, Italy)

When I was in my own country, I don't know about asylum but the intention is to be free, to be safe.

(Ophelie, focus group no. 2, Glasgow, UK)

\subsection{Introduction}

According to the United Nations (UN), at least 258 million people are moving across countries around the globe, consciously or unconsciously, in search of a safe and dignified life (IOM 2019; UN 2017). The international attempt to regulate these movements through the so-called Compacts seems unlikely to provide effective solutions. ${ }^{1}$ Often criticised as being non-binding instruments but with great potential in shaping states' future behaviour (Türk 2018), the Compacts are not explicit in including SOGI minorities in the measures to be adopted through international cooperation for improving the management of migration and refugee flows, while respecting their human rights. It is noticeable that objective no. 7 ('Address and reduce vulnerabilities in migration') of the Global Compact related to migration refers to 'victims of violence, including sexual and gender-based violence (...) [and] persons who are discriminated against on any basis' as examples of

\footnotetext{
${ }^{1}$ UN General Assembly, Global Compact for Safe Orderly and Regular Migration, adopted at the seventy-third session, 19 December 2018; Global Compact on Refugees, adopted at the seventythird session, 17 December 2018, A/RES/73/151. The Compacts follow the adoption of the New York Declaration for Refugees and Migrants, adopted at the seventy-first session, 19 September 2016, A/RES/71/1.
} 
vulnerable groups and, more generally, advances the development of genderresponsive migration policies (Atak et al. 2018). Equally, the Global Compact on Refugees pays attention in all fields to 'sexual and gender-based violence', while calling upon states to strengthen international efforts to prevent and combat it (paras. 5, 13, 51, 57, 59, 72 and 75). Yet, although this wording may be inclusive of SOGI, the Compacts avoided any specific reference or commitment in relation either to migrants who identify themselves as LGBTIQ+ or to SOGI claimants, perhaps owing to the need for the widest possible consensus among UN member states to secure the Compacts' adoption. This represents a missed opportunity to raise awareness of SOGI asylum claimants' needs at the universal level and speed up multilateral solutions to the movements across countries of people fleeing homophobia and transphobia.

Yet, as Victor Madrigal-Borloz stated, for many SOGI claimants 'the trauma and persecution start well before their actual flight to safety', while 'the journey to safety can prove particularly treacherous [because these claimants] continue to face prejudice and violence in countries of transit and host countries' (UN Independent Expert on protection against violence and discrimination based on sexual orientation and gender identity 2019). Therefore, he called upon states to grant 'safe settings' well before the asylum process starts in the receiving country, in order to cover also their often long-term travels and stays in transit countries. This opinion is also shared by some European policy-makers. As Terry, a member of the European Parliament, explained:

\footnotetext{
Very often we start looking at a process of fleeing when the person arrives in the European Union but, actually (...) there is a long process before that. And the question would be, how can we actually make sure that people get legal entry ways that don't include (...) being on the road for weeks or even months in very vulnerable situations?
}

Significantly, SOGI claimants also perceive us to be experiencing a particular historical moment. According to Diana (Germany), 'the refugee concept has changed a bit from seven years ago (...) we did not have a refugee crisis like now'.

For these reasons, this chapter aims to analyse the complex situation faced by SOGI claimants before they leave their countries of origin, during their travel to, and arrival in Europe. Considering the paucity of studies in this specific area of SOGI asylum (Danisi 2018; Piwowarczyk et al. 2017; Winton 2019), and the fact that these are often country specific (Munir 2019; Odlum 2019) rather than addressing the multinational journeys that occur, this chapter also explores the implications of these journeys for SOGI claimants' experiences with the asylum process. As Chiara, a psychotherapist who works with migrants arriving in Italy through the Mediterranean Sea, explained, the experiences of SOGI asylum claimants are complex, and besides the abuses suffered in their home countries, their travels are also 'a synonym of violence and ill-treatment'. The reception systems in Europe, which should provide appropriate support at arrival, are instead the cause of additional trauma. 
As context for understanding SOGI claimants' subsequent experiences in Germany, Italy and UK, this chapter first looks at their lives in their countries of origin, including their social experiences and family relations, and, through these lenses, at the treatment reserved to SOGI minorities in those countries (Sect. 5.2). Recognition of the importance of these aspects of life in countries of origin may facilitate subsequent analysis of how SOGI asylum claims are assessed and whether or not claimants' personhood is respected by European decision-makers (Chap. 7). Second, by questioning the lack of alternatives to asylum, including the possibility of obtaining humanitarian visas under IRL and IHRL, this chapter considers whether SOGI claimants are aware of the possibility of claiming international protection in Europe on the basis of their fear of persecution on SOGI grounds and whether their travel routes are consciously chosen. The travel experience is also investigated, in an attempt to analyse whether and how it influences the subsequent asylum application and wellbeing in host countries. Third, by exploring the procedures upon arrival in Europe, this chapter verifies whether or not host countries provide the 'safe settings' advocated by the UN SOGI Independent Expert (Sect. 5.3). These settings include, at the very least, the existence of effective means for informing claimants about the possibility of seeking asylum on SOGI grounds, as well as an assessment of the protection needs of each individual (Sect. 5.4). Some provisional concluding remarks are provided in Sect. 5.5.

\subsection{Life in the Countries of Origin}

While often disregarded in SOGI asylum analyses, understanding the life experiences of people claiming asylum on SOGI grounds beyond persecution is essential to the intersectional and integrated approach advanced in our theoretical and analytical frameworks (Chap. 3). Focussing attention only on episode(s) potentially amounting to persecution risks ignoring not only fundamental aspects of claimants' personhood but, also, relevant data that may contribute to shaping fair asylum decision-making.

For this reason, we investigate: how SOGI claimants saw their lives before being forced to flee; what their social experiences were, including activism for SOGI equality; and what their perception was of how SOGI minorities are treated in their countries of origin. While a number of NGOs and international organisations have reported on the legal treatment of SOGI minorities (Ramón Mendos 2019), the insights of our participants on the social environment that determines the life experiences of SOGI claimants shed light on a largely unexplored area. Here, we offer, through SOGI claimants' lenses, an analysis of these pre-departure experiences. 


\subsection{1 'Ordinary' Lives}

It is often assumed that SOGI claimants left a life of absolute misery for a life of absolute freedom. Yet, such an assumption reflects an over-simplistic paradigm of persecutory and protective countries. In fact, experiences are far more nuanced.

One of the recurrent feelings shared by people claiming asylum on SOGI grounds appears to be the sense of frustration at having been forced to leave their 'ordinary lives', including everything they had built up over the course of their lifetime. This includes family, social and love relationships, as well as employment, all aspects of one's private and public life protected by IHRL (for example, Article 17 ICCPR or Article $8 \mathrm{ECHR}$ ). As a result, against all sort of related stereotypes still popular among decision-makers (Chaps. 6 and 7), SOGI claimants do not always show a total rejection of their countries of origin (Giametta 2016, p. 68). At the same time, feelings of disempowerment may shape their individual experiences after arriving in Europe, as we will see across these volumes.

The case of Alphaeus (Germany) is illustrative: 'I was an engineer before in my country. I had my own company, a construction company. And unfortunately that all ended like that'. A similar experience was shared by Sandra (Germany):

In my country I worked, before everything went bad, I worked, so I had my own place, my own space. Yes, I understand people flee for different reasons. Some lose their parents, some lose their families but, at the end of the day, you lose something. I had all this (...) I had plans for my life, I had goals to achieve, and things were really going the way that I had planned. And I was there and seeing my friends, being happy (...) in my country we buy land, pieces of land and build houses. [Now] I'm like... I felt like a failure.

Kamel (Italy) shared similar feelings: 'I left a family, my job, my house, my friends, my lover... I left many things. I left a country'. Equally, Kennedy (Italy) stressed: 'If they can amend the laws tomorrow, I will be among the first person to... voluntarily to go, because before I left, I was still having a life'. As Ibrahim (Germany) reiterated: 'Despite the stress, I did have a structure and community and I didn't want to leave all of this behind'. Alphaeus concluded: 'If I'm told Uganda is better [in terms of LGBTIQ+ rights], I go back to my country because I had a life'.

This sense of loss and disempowerment, which has clear consequences also for integration in the host country (Chaps. 8 and 9), is expressed well by Marhoon:

I've worked in Oman for ten years, so that the retirement money that I've paid from my own money has been lost. Ten years! I will not have it here in Germany. (...) Are they going to employ someone who's 24 or someone who's like me [much older]? Will I have a senior position like I used to have in Oman? (...) I have all these questions and all this confusion.

The only solution remains the one indicated by Milad (Germany): 'I had to start from scratch. Building zero. It was really difficult'.

These accounts of positive experiences, relationships and achievements in claimants' lives in their countries of origin need to be balanced by experiences of discrimination, abuse and forced concealment of their SOGI. In this respect, Ibrahim (Germany) remembered: 
I stayed in a Lebanon jail for five years. (...) My family had an idea - if we put him in jail away, jail makes boys into men and people will forget his issues, that he is a sissy boy (...). And they made for me a case of drugs, just to put me away.

Bella (Italy) also evoked how her life changed when some people found her with another woman:

They started blackmailing me to bring money (...) so that they will not take you to the police. (...) Before escaping, I was paying but I could not [do it anymore] because I was the one taking care of my child.

\section{Similarly, Lutfor (UK) explained:}

I tried my best, to stay in Bangladesh. (...) It is your country, you can speak to them and (...) I had a very good result [in] school, college so, if I could hide my sexuality, if I didn't come out, I could go [to a] top level job, government job. I had to give up.

In these environments, the ability to express one's personhood is seriously restricted. In this respect, Marhoon (Germany) explained his experience as an exception:

I was very comfortable with my sexuality since I was 19 , so even on dating apps I would use my face, which was very rare in Oman. Most people don't use... I didn't lead a double life, I didn't have a wife or kids. Most guys did in Oman.

\section{Equally, according to Milad (Germany):}

We met in some secret places that we only know each other. We also had the apps (...). But was not public. Was always private. (...) with friends drinking tea, drinking coffee, talk, go for a walk (...) to the cinema. [But] I was always careful.

Kennedy (Italy) recalled how having a relationship is nevertheless possible in these difficult circumstances:

We fell in love, year 2008. So we were together, although it was secret, strictly secret, nobody knows about our relationship. But the reason why we have the greatest opportunity [is] that I have my own house, so he normally comes, he comes, he sleeps any time he likes.

Yet, an ambivalence between a desire for the lost country and the realisation of things SOGI claimants can enjoy in Europe also emerges powerfully, especially when religion plays a key role in shaping oppressive social environments. As the experience of Meggs (UK) shows:

Zimbabwe is a very Christian country, so homosexuality is just a sin. (...) you grew up knowing that (...) you are not supposed to do it and you are still trying to find yourself (...) and say "this is who I am". (...) Regardless of the economy and everything (...) sometimes I wish I was home. I love, I love Zimbabwe (...) I am only seeing it now that it was really bad. But, I just grew up knowing that if I have got tea morning, if I have lunch and I have dinner in the evening, that is all, so to me that is how it used to work and it never used to bother me.

This does not mean that SOGI claimants are always able to exercise greater freedom after they arrive in Europe. As Fares explained in relation to his fellow nationals:

I don't have a lot of friends from Syria here in Germany. Not all the Syrian gays came out and say that we are gays, they're still in the closet. Here in Germany, there are a lot of 
people from Syria, so we cannot come out directly. [But] You should be proud of yourself, because every time when I was in the closet, I was thinking "oh my God, I'm ashamed, I'm something bad", [and] I prayed to God to change my life, or to be straight.

People who were involved in activism before fleeing their country experienced additional difficulties. In fact, despite the restrictions they faced in their countries of origin, many people fleeing homophobia and transphobia described their activism in Nigeria, Malaysia, Oman, Egypt and Zimbabwe, to give a few examples. Interestingly, the term 'activism' acquires a broad meaning in similar contexts, because it is not restricted to the political dimension.

For Marhoon (Germany), activism meant 'gather[ing] people in private spaces (...) because [Oman is] a segregated society (...) and [I] like[d] to build a community'. Most of the time, the willingness to campaign for certain social issues was hampered by the fear of making one's SOGI public. In fact, Kennedy (Italy) reported:

We [were] thinking what could we do to stop the massive killing (...) of the homosexual people in Nigeria? [We wanted] to sensitise the people (...) we came out not to say "we are gay", but we [came] out, you know, to tell the public that they should stop killing.

Besides the fact that open activism in relation to LGBTIQ+ issues was rare, attempts to register or formally establish associations often failed. Amber (UK), fleeing Malaysia, said:

We can't explicitly say we are campaigning for LGBT rights, otherwise we will get into trouble. [We tried] to register our organisation with the Home Ministry (...) but we were never granted status, even after appealing. So our resources are limited with no funding.

As Ximena (UK) also confirmed, the price to pay for carrying out such activities extends from threats to one's safety to the need to flee the country.

This kind of involvement with SOGI activism may have a positive impact on asylum decision-making. As Louis, a volunteer from Rainbow Refugees Frankfurt in Germany, suggests, experiences of activism in the country of origin may speed up the evaluation process, while in their absence 'it takes much longer'. Moreover, according to Roberto, a decision-maker in Italy, activism in fields other than LGBTIQ+ campaigns may also be relevant for granting refugee status on SOGI grounds if the activities attract 'a certain visibility'. This is also relevant for countries where no laws criminalising same-sex acts are in force, such as Eastern European countries, where 'social' persecution may, nevertheless, be prevalent, as well as for the use of other grounds beyond PSG during the evaluation of the asylum request. While we will return to this matter in Chap. 7 , data related to the treatment of SOGI minorities in countries of origin are particularly rich and deserve specific investigation. 


\subsubsection{Treatment of SOGI Minorities in Countries of Origin}

To this day, approximately 75 countries still have in force legislation criminalising non-heterosexual and non-cisgender identities and/or behaviours (Ramón Mendos 2019). This information alone, however, does not reflect what living in one of these countries means to SOGI claimants. The effect of such a legislation on claimants' lives may vary to a significant extent. To use the words of Ibrahim (Germany), fleeing Lebanon:

I have my scars, I have hospital reports, I have everything with me, that I faced violence, discrimination and so on. But not all LGBT people face violence. Maybe, people just flee because they want to live a decent life, they want to live life with love, to love what they want, to live their true identity.

With this in mind, the perspectives on the social environment in their countries of origin that SOGI claimants shared were enlightening. To illustrate the range of treatment suffered by SOGI minorities worldwide, an analysis per country of origin, which is connected by claimants' experiences, is appropriate at this point.

Starting with participants from Africa, Rosette (Germany), fleeing Uganda, explained how pervasive homophobia is across different life spheres in her country of origin:

We were disqualified from that school [after I was found being intimate with another girl] and then my parents were really mad about me and (...) I was transferred to my uncle's place. (...) My mother said that she doesn't want to know what I am, who I am, whatever. She didn't even take time for me to explain how I feel. (...) But when the [uncle's] wife also realised why I was disqualified from school, then he [the uncle] also turned blue, he really did not want me to associate with (...) their kids. (...) One day my mother came and said "now we have to go back to town". I was happy [but] what I didn't know was that she was going to force me to marry. (...) I was so frustrated, very frustrated, and I felt like dying but I could not kill myself. (...) All that time I stayed together with that man, it was as if he was raping me. I was married for 18 years. (...) In Uganda you can't survive. (...) They will say no, how? Why? You have a demon, they believe that if they put a sword on you and cut, bleeding you, that the demon is getting out, that's what they believe.

Alphaeus (Germany), also fleeing Uganda, confirmed this by stating that ' $[\mathrm{t}] \mathrm{he}$ time I left, it was a terrible time where many gay people were castrated, many gay people were being beaten badly'. William (Germany) had a similar view:

Uganda is a country where the police and the government and the law are so strict and they cannot allow it. Then you talk about the people and their culture. [They] cannot allow that to happen. Never. Never! You cannot even talk about it.

According to Aisha (Germany), in Uganda:

We are not taken as people who understand. Many people, they think we are mad, we are crazy (...) when they found out that I'm that, they take you like you are not a human being, you are not supposed to be with them together. They take you like they have to stone you to death. 
Referring to Nigeria, Nelo (Italy) stated: 'They look [at you] like an animal, so they describe this thing [like] you are an abomination to the land'. Patti (UK), fleeing the same country, stressed:

When you talk about it, some of the family, they kill the person because they think that that is a shame to the family, if other people got to know about it. Or, one demon has possessed this family, or they are a cursed family (...) and no one will want to associate with the person. Even me, as a hair stylist, and I am going to let people know about it, some of them won't want me to touch their hair. They think "oh, she is possessed". (...) So, I don't know when that is going to come off from Black people's head, it is like, no go area.

Silver (Italy), who explicitly refused to hide in Nigeria ('I can't say I'm not gay. I was born this way'), recalled that a friend suggested to him 'If they see you, they understand that you are gay, so stay at home. (...) You can't live in Abuja, because if they find who you are, you will be dead'.

Similar perceptions of the Nigerian social and cultural environment were shared by Tina (Germany), Kennedy (Italy) and Bella (Italy), among others. As Kennedy put it, '[if] you are gay or homosexual, lesbian, you are enemy to the state, and to the members of your family, to the members of the society'. Bella further explained:

Even if I am not a lesbian (...) they will say "no, she is a lesbian, you see her (...) she is following girls". (...) Without seeing you as a lesbian, without maybe catching you doing it (...) everybody will hate you. Everybody will discriminate you, you know, look as if you are alone.

This degree of rejection may reach the level described by Momo (Italy), fleeing Senegal:

When they knew that I'm not a simple man, that I'm gay, no one wanted to see me again (...). Mums love their children. When children are gay, many mums try to protect them, but many others don't. Some mums may even kill you in your room when they discover that you are gay.

Diarra (Italy), an asylum claimant from Mali, explained that, in his country, even for his mother life could become unbearable if people found out about his sexual orientation:

When they know that you are gay, they beat you with a cane to death. People say that our country is a Muslim country and homosexuals do not exist. They do not want [to] even hear that word. (...) Change these people's mind, it is not easy.

Siri (Italy), from the Ivory Coast, explained in turn that in his country:

If people get to know that you are gay, you can be killed, because you can be stoned by some or be beaten with sticks by others, you'll be struck, they will beat you up, while other[s] will film you for uploading your picture onto social networks, your face on social media.

Dev and Fred (Italy), who fled Cameroon, also referred to 'popular justice': 'Homosexuality (...) is punished with a one year prison sentence by Cameroonian law and, above all, even with a condemnation to death by popular justice'. As Irma, who arrived in Germany from Cameroon, further explained: 
Where I come from, they are looking at it, taboo. That you break the culture, you have given a shame to your whole family. (...) They will call the chiefs (...) of the village, they will follow protocol, kill you or send you to prison. Before then they can even isolate you from the village.

Alain A. (Italy), also fleeing Cameroon, stressed that homophobia is a cultural problem:

These people are treated like animals, they are treated like they are not human beings. (...) And you are an outcast in the society because first you lose your family, then you lose all the friends you have, and then everywhere you go in the society you are being haunted by the people because of your sexual orientation. So, at times so many people don't even get the chance to experience their life or to try to, like, discover who they really are because of the society. So, being homosexual or having sexual orientation problem in Africa in general, and again my country, is very, very, very, very horrible. (...) And if somebody kills you because you are homosexual, the person is not penalised. (...) It is not about the government accepting, it is about the population. The government can say "yes, we support samesex marriage", but you will still face torment and the people don't want, the problem is the people, cultural, Africa is like so hooked up to culture and religion.

Finally, according to Martin (UK), the Cameroonian police takes a particular and negative approach towards SOGI minorities:

They look at it like it is abnormal, it is a witchcraft, you are just like practising something, you know what I mean, you are in a cult which you do that to kill other people, so they look at you like a threat for them. (...) You might be rescued by the police. But they will take you to prison, and you have no right to a lawyer to talk to, you have no right to people to talk to, and the police themselves they are part of the population. They have the same feeling, they have the same belief, the people who are supposed to protect you, they will be the one basically hitting you, oh my God, I don't want to talk about it, hopefully you don't get raped there.

In contrast, Amadin (UK) reported some differences between the behaviours of the authorities and the population in Benin:

The law punishes when you act. (...) As you are gay or lesbian, they don't bother who you are. (...) So, in Benin the problem is the community. (...) If, like, two men kiss in the street, the community can get beating (...). And some time when they call the police to say the police must come, the police say they cannot waste their time to come. But sometime they can come and they come to lock you.

Experiences in Malawi have similarities with those in the countries already mentioned. Stephina (UK) described the situation in her country of origin stressing that the information available in the UK about Malawi does not correspond to social reality:

In my country, they said, people are no longer put into prison and nobody is taken into custody. [But] my worry is if the community decides so (...) the government is not going to come to my rescue. (...) Recently there were so many reports of people being killed, like, there were videos everywhere of people being stoned by communities, because they are suspected that they are blood suckers. (...) Even the president says we are like dogs that eat our own vomit. So, the law would say one thing, but the reality is another.

Buba (Italy), from the Gambia, confirmed that, despite public announcements, nothing had changed in practice with the new President coming into post. Diamond 
(UK) also referred to Tanzania as a society that is particularly homophobic and homophobia remains unpunished:

It is very illegal. (...) They will just start beating you. They might even kill you. And they don't have anything for them to... go and complain or nothing. Because if you go and complain to police, they will torture you. (...) Even the family, family, people, anybody, nobody will give you support. (...) Because government itself, the president at the moment, he said that gay are like a cow, he has already mentioned us in the category of animals.

As Sandra (Germany), also fleeing Tanzania, confirmed:

They will just start chasing you with stones and calling you a thief or someone will just say "a thief!", then everyone comes chasing you, they beat you, then they take tyres, put them around you, put some petrol over them and then light you openly on the street.

Similar patterns of social intolerance towards SOGI minorities were expressed in relation to Zimbabwe: '[t]hey are a strict Christian country, they don't accept that. And it is not only the government, it is the community' (Meggs, UK).

Pointing out the impact of well-reported homophobic events involving SOGI minorities, Ibrahim A. (UK) from Egypt explained that the absence of a law criminalising homosexuality does not ensure better treatment for SOGI minorities in Egypt:

There is a continuous LGBT crackdown from the government since 2013, after the military coup. (...) There is no law that criminalises homosexuality but... we have the combatting prostituting and debauchery law, so the government applies the article of this law on homosexuals.

Moreover, new technologies are actively used to identify members of SOGI minorities:

The internet revolution and the online platforms [were] somehow a way for LGBT community to communicate with each other. And it also start[ed] a new age of... criminalisation for LGBT. Because even the government was using the same platform to start to entrap gays and transgenders and take their activity online as an evidence even for their sexual orientation (Ibrahim A., UK).

Selim (UK) further explained this trend in Egypt (as well as in Dubai, where he lived for a few years):

I have seen a lot of my friends getting killed and that is on daily basis (...). People disappear. (...) And, I don't even know how many times we used to switch off our phones right after, you know, someone has disappeared, one of the group disappears and that for us means is arrested, they are going to go through his phone and they are going to try and find us as well. So we just switch our phones off, we disappear for months. (...) Grindr on his phone, he is chatting to this guy for a while now and then finally they decided to go and meet, he goes to meet him and it was just the police.

Finally, Shany (Germany) stressed the total denial of their existence experienced by SOGI minorities in Morocco:

The idea is lesbian or gay, it is a taboo (...) you go to the jail. (...) It's a big crime, it's a scandal. (...) You give no respect to the society because there is no lesbians and gays, they don't know this word. It's forbidden, it's not in the society. 
Moving toward the Middle East, accounts of violence and abuses, including by family, were also given about Iraq and Syria. Fares (Germany) remembered that, in Iraq, one of his friends was beaten very badly by his parents when they found out about his sexual orientation and they stopped feeding him, as they considered his sexuality to be a shame for the family. Fares also emphasised the role played by religion in determining SOGI minorities' lives in Syria:

In Syria, in the school we study the Koran. We should study that. They start to put in our mind LGBT or gays, LGBT community are something bad, they will go to hell and these things. And you shouldn't do that, and do this. (...) I thought that I'm totally alone in this world.

Diana (Germany), instead, pointed out the 'multifaceted' approach in Iran towards SOGI minorities:

If someone is obviously gay or lesbian or something like that, it can turn into jail and then kill - so not be alive anymore. But that's also different levels. (...) And of course that's from the person who is [sexually] passive, that's killing. When [penetrative] active person is different. (...) Only transsexuality is acceptable - that is legal. (...) Many gay and lesbian people as trans also do these operations. Because they think if they change the sex, that would be better to live in Iran. (...) That is only legal. Socially, of course, that's taboo.

SOGI claimants from other regions, like Eastern Europe, Asia and the Caribbean, shared analogous difficulties and ill-treatment, whether or not criminalising laws are still in force in their country of origin. A few examples are illustrative. Referring to Russia, which is a member of the Council of Europe and ratified the ECHR, Veronica (Germany) explained: 'Other people are allowed to behave aggressively and say and beat, bad words, so openly, because they see what comes from the state. (...) That's hard to really live openly in Russia. And for men, I mean, worse' Similarly, Prince Emrah (Germany) explained in relation to Turkmenistan:

If I go to Turkmenistan, they will take me to jail again. (...) You cannot be openly manly, you cannot be openly feminine. You cannot go to the clubs as gay. When they see you, they catch you (...) they give you four years, five years to sit in the jail.

The persistence of 'cultural' beliefs about SOGI minorities was stressed by Sadia (UK) with reference to Malaysia: 'My uncle think it was the devil coming inside my body'. Such accounts confirm the strong influence that religion plays in that country in this respect. In fact:

[They] do have laws that specifically legislate to curb LGBT people and its "lifestyle", especially Sharia law, because Malaysian society is predominantly Muslim and Malaysia made Islam as the official religion in its constitution. (...) Especially if you are trans, there is a specific Sharia law against cross-dressing in every 13 states, basically saying if you are caught dressing up as the opposite sex and doing immoral acts (loose term for prostitution), you can be prosecuted. And in three states it just simply stated that you can be prosecuted if you step out of the house while presenting as the opposite sex or crossdressing. And for gays or lesbians, who might be presenting too femme or butch respectively, they could be approached by self-righteous "religious police" offering unsolicited advice to return to the right path (Amber, UK).

Jamaica is another case in point. Angel (Germany) explained that: 
The church uses the buggery law against every member of the LGBT community. (...) It's embedded in your mind from when you're a child that lesbians must die, gay men must die. And they don't say lesbians, they say "sodomite". They don't say gay men, they say "batty man". (...) I've had partners that I've had to tell people that she's my cousin. (...) You can't be a transgender in Jamaica, because a man can't put on a woman's clothes (...) you will die by the time you step through your door. Your neighbour will kill you. (...) When straight heterosexual people kill them, and no police is investigating, and on top of that the parents are not going to claim the body and bury it.

As Trudy Ann (Germany), also from Jamaica, summarised: 'As a man you can never be girly, you have to tug that out because you would be like dead meat'.

The pervasive legal and social homophobia and transphobia evident in these claimants' experiences throws doubt on the possibility of improving SOGI minorities' enjoyment of human rights through law alone, including by undertaking international commitments. A more encompassing cultural and social 'revolution' seems necessary. South African experience confirms this difficulty (Camminga 2018, 2019). As Junio (UK) explained:

There are different ways that they are treated. Firstly, they are met with the stigma of the community, even though there is a constitution that supports LGBT people. (...) LGBT people in South Africa have a difficulty to express themselves (...) they can't because of the community and the traditional leaders. (...) Then there is corrective rape that unleashes from the community to LGBT people and access to healthcare is very limited, jobs as well. (...) The police is not really doing much. (...) So, most cases go unreported for the sake of that fear.

The overall implications of past abuses and discrimination on the 'new' life in Europe are evident in a Syrian claimant's words:

[I]t was hard [to get used to life in Germany]. Because I saw the culture, it was a shock for me because in Syria we can't do anything, we cannot do anything to hang out, to kiss a guy or to hold his hand on the street. (...) Because if you do that you will go to the jail or the community will judge you. It's going to be really horrible (Fares, Germany).

Indeed, the habit of living one's SOGI in the 'closet' to avoid persecution makes living in a more open environment difficult at first. In sum, for many SOGI minorities, it was the social and cultural environment of their countries of origin, as much as the law, that made life intolerable. As Just Me (focus group no. 3, northern Italy) expressed very clearly, '[s]ome people live with that fear every day in Africa, day to day. It is always their secret, always afraid for people not to know about your sexual identity'. When the need to flee becomes overwhelming, new challenges lie ahead, as the next section explores.

\section{3 'It Suddenly Happened'}

The previous section has shown why, while some aspects of people's lives may be relatively satisfactory, the constant presence of homophobia and transphobia forces individuals to leave their country of origin. Yet, the decision to leave is rarely 
followed by an easy process of departure and travel towards a 'safe haven'. The main obstacle is the general lack of legal channels for escape, including to European countries, which forces claimants to find alternative solutions rather than use direct, safe and legally recognised pathways. As anticipated in Chap. 4, even legal channels such as family reunification are often not an option for SOGI claimants (Del Guercio 2018) owing to a still widespread heteronormative reading of the notion of family, which contrasts with our theoretical framework (Chap. 3).

The current extent of territorial and extraterritorial control of state borders, particularly those of the EU, means that it is increasingly difficult to reach a safer country in order to lodge an asylum application. This is not a new phenomenon, as historical analyses have confirmed (Scott FitzGerald 2019), in light of states' 'undeniable sovereign right to control aliens' entry into and residence in their territory'. By applying an 'embodied border paradigm' in relation to EU migration and asylum law, Violeta Moreno-Lax demonstrates how external borders, set up at the European level inside and beyond the EU to exercise this sovereign right, now constrain all migrants (Moreno-Lax 2018). People seeking asylum, including SOGI minorities, are prevented from reaching Europe through the deployment of a variety of legal and institutional mechanisms and enforcement controls, not only at European borders but also in transit countries. In sum, these macro-level factors may suggest that European countries are primarily implementing their Refugee Convention-related obligations by pursuing their own internal interests, thus stretching the exclusionary rationale embodied in that Convention (Chap. 3) rather than adopting a human rights-based approach.

The international legal framework leaves states with significant room for discretion in this field. Doubts have been raised about whether IHRL includes an obligation to issue humanitarian visas, thus granting people who are in need of international protection a 'safe passage' to destination countries, even before the formal submission of an asylum application (Danisi 2019). Despite the fact that every individual, regardless of nationality, is entitled to enjoy certain human rights and freedoms, human rights treaties apply only 'within the jurisdiction' of contracting states. Unless the notion of 'jurisdiction' is framed along the lines of more progressive models based, for instance, on the impact of decisions refusing 'safe passage' in order to claim asylum, ${ }^{3}$ human rights play a limited role, mainly through the principle of non-refoulement or procedural obligations once the asylum application is already submitted at the borders of the destination country or within its territory. ${ }^{4}$ An obligation to issue humanitarian visas cannot be established under EU law either, as the CJEU found in $X$ and $X .^{5}$

\footnotetext{
${ }^{2}$ Taking into account the ECHR, for instance Saadi v. UK, Application no. 13229/03, Grand Chamber, 29 January 2008, para. 63.

${ }^{3}$ HRC, General Comment no. 36, 2018, paras. 5-7. For an analysis of this model, see Danisi (2019).

${ }^{4}$ For example, when a European country has control over a claimant's life, such as on high seas: Hirsi and Others v. Italy, Application no. 27765/09, 23 February 2012.

${ }^{5}$ Case C-638/16 PPU, $X$ and X, 7 March 2017, ECLI:EU:C:2017:173, para. 51.
} 
For people fleeing homophobia and transphobia, as for many others, such an obligation to issue humanitarian visas would help avoid the additional layers of violence and abuse that this section, through the personal accounts of SOGI claimants, explores. It should be noted, however, that it may be easier to cross European borders when exceptional situations arise, putting specific groups in a position of relative advantage for reasons unrelated to SOGI but that, nonetheless, may have a positive effect on people belonging to SOGI minorities. This was the case of Ibrahim (Germany): whereas humanitarian visas were issued for some people following the war in Syria, Ibrahim was not Syrian and was denied a visa in European embassies in Lebanon. Nonetheless, Ibrahim took the opportunity to escape homophobia and travelled to Germany via Turkey, Greece and Macedonia:

Since I was 17, 18, I always had the dream to live in Europe, because I saw this parade on YouTube. (...) But I never believed that I would be here one day, until that day of what happened. In Syria, the war, the borders [were] opened. [H] ow should I come? I won't have a visa, I won't be able to come here. So, I guess sometimes war was positive for some people.

The same phenomenon occurred in Italy, where Anna, an LGBTIQ+ group volunteer, told us about the case of a bi-national couple where the Syrian partner in the relationship did not need to apply for asylum on SOGI grounds, as he had obtained international protection owing to war-related events in his country of origin. Similarly, the UK's Syrian Vulnerable Persons Resettlement Scheme (Chap. 4) takes people identified as vulnerable by the UNHCR, which may include individuals at risk owing to their SOGI.

Other useful mechanisms for protection are humanitarian corridors, which may have a general scope, as reported in Italy (for instance, Valentina, social worker) or may consist of more limited initiatives devised for SOGI claimants with NGOs support (Angel, Germany). These scenarios, however, constitute exceptions to the experiences of most SOGI claimants, especially if compared to other national experiences like Canada's dedicated resettlement programme (House of Commons Canada 2017). In the following sub-sections, we explore the experiences of forced departures and travel, including the treatment suffered in transit countries.

\subsubsection{Forced Departures}

Our data show that, most of the time, neither the decision to flee a country nor the final destination are planned by SOGI claimants. More often than not, these follow unforeseen events. As Shany (Germany) put it, after a family member discovered her sexual orientation, '[a]ll my life I was working, I didn't have any, any kind of any problem... [Other people] plan their coming (...) all their lives. This is the difference between me and them (...): I didn't plan it'. Not surprisingly, she continued as follows: "it was something like, "I have to do it, I have no way". (...) The life in my place [was] not possible anymore'. Equally, Selim (UK) explained: 
[Asylum] is a term that never crossed my mind before. Like it was nothing, it was never planned. I had a good life, I had a good career. Lots of people wanted to be in my position, but I was always unsafe because (...) you wake up every morning in the Middle East and you draw this line on your face that you are straight, but you are not.

A similar experience was shared by Diana (Germany): '[T]he goal was simply to leave Iraq. So that was not a decision where or where to go'. The most common experience is expressed well by Jayne (UK): 'It wasn't anything to do with choices at that point, I was kind of desperate'.

Nonetheless, our data include some SOGI claimants in all countries under comparison who had planned their destination and journey. For instance, Janelle said: 'I chose to come to the UK. I did my research in terms of gender identity, the laws of the country, and it was my place of choice'. The same experience was shared by Tiffany (focus group no. 2, Glasgow) who explained: 'I escape[d] from home, to go to UK because I know in UK... people with sexuality to live freely and openly'. Still, as Kamel explained, decisions may not be entirely freely made: 'Italy was not my choice, not at all. I have gathered information on all countries of the world in relation to my situation, but the only place I found doable was Italy'. Even when planned, there is no guarantee that the chosen destination will be reached. For instance, Alphaeus explained: 'When I reached [Germany] I struggled still, because I wanted to proceed my journey, to continue to go to Finland. (...) But the police told me "you're not going anywhere"”. In turn, Sadia remembered: 'No, I [didn't] have any idea about UK, but my sister just [told] the agency [to] give [me] any place for just a safe place'. What she meant by 'the agency' was not, however, clarified.

These accounts lead us to what some participants referred to as the common story of many claimants claiming asylum on grounds of sexual orientation (for instance, Diego and Riccardo, LGBTIQ+ group volunteers, Italy). As reported, such recurring scenarios generally involve two people, the claimant and their partner, who are found in intimate or sexual circumstances in someone's home (or less commonly, at school or at work). What follows may be expressed in the words of William (Germany): 'I was naked and my partner was also naked. (...) They forcefully entered. (...) They started beating me, shouting "you are promoting homosexuality in our village". (...) They dragged me outside [and continued] beating [me]'. Often, what happened to the partner is unknown and, even where the police intervenes, such accounts commonly include arbitrary mistreatment, interrogation to identify other LGBTIQ+ people, eventual release from imprisonment (sometimes after the payment of bribes), and an immediate attempt to escape the country, which, by that time, seems the only possible solution. As always William explained: 'I could not go back to the village because I was now a vagabond, I was now an outcast'.

In these particular circumstances, the option of resorting to humanitarian visas, even if available, was deemed problematic by some participants. Fred (Italy) explained: '[For visas] you need to wait and wait. But when a person experiences a problem like the one we [SOGI minorities] have and apply for a visa, when will it be provided?' The same difficulty is expressed by Fido (focus group no. 4, northern Italy): 
You know why people will not ask [a visa] from Nigeria, and come to Europe through flights or whatever (...)? Because when you are living your life, you don't have any problem, you would not think of going to Europe. (...) [T] he problem occurs immediately, no one out there would think "let me go to airport and go and prepare my visa and take flight", it is not possible when they are looking for you. The next opportunity is your road.

Our data also demonstrate the persistent and ongoing nature of persecution experiences in countries of origin before the final decision to flee. To use the words of Halim (Germany):

I had certain incidents and threats from the government (...). I used to dismiss those fears and threats for a long time. However, by the end of 2014, I felt I [was] no longer safe in Egypt, [because it became] increasingly dangerous, friends of mine [were] arrested.

In other cases, relatives and friends play a key role. Sandra (Germany) explained that:

I didn't know that I would be a refugee, but a friend of mine who is in France (...) he knew my problems, and he told me to leave the country (...) I had to quit my job, I had to quit everything and just not exist. (...) If it wasn't for him giving me a way out (...) I don't know, maybe I would still be living inside [my country].

When escaping persecution, protection is often sought and, sometimes, temporarily obtained through personal contacts or socio-economic connections in the country of origin, thus avoiding forced and immediate departure. A first example of this is provided by Sandra (Germany):

I had to move [to the house of my best friend's sister] because I knew that nobody would ever suspect me being there. She took me in because she lived maybe 15 years in the states. (...) She's a lot open minded, so for her it was ok, and that's where I stayed all this time.

A second experience was shared by Marhoon (Germany), who came from a privileged and well connected family in his country of origin:

When people see it [my name], immediately they change their attitude towards me. I'm respected automatically just because of my family name and title. I was caught once with a guy in a car kissing, having sex, not only kissing (...) by the police. I thought ok, I'm done, my family will disown me. (...) Then, once they saw my ID card, they said "ok, go home".

While these experiences are unusual, such 'private' and limited protection is immaterial for claiming and being granted international protection. In fact, the availability of a private, relatively safe environment, is no surrogate for state protection and does not reduce SOGI claimants' fear of persecution. In this respect, Sandra (Germany) herself pointed out that '[y]ou just wake up with a cancer. You don't plan to have it. So it's either you die or you survive from it'.

These experiences of forced departure are aggravated by the need to undertake dangerous routes, often with the involvement of smugglers and harsh treatment in transit countries - harsh treatment both for their 'refugeness' and as members of a SOGI minority, as our intersectional approach suggests (Chap. 3). 


\subsubsection{Journey Experiences}

Travel experiences were described as extremely traumatic by professionals working directly with arrivals in Europe, in line with 'desperate journeys' of migrants already documented at Europe's borders (UNHCR 2019). For example, Susanna, a social worker in Italy, explained:

We are talking about extremely vulnerable people, not only because they are claiming asylum on sexual orientation grounds, but also because they have gone through such a tough journey that they arrive here with an intermingling of psychological issues, including sometimes a certain amount of apathy, as well as restraint in showing their inner feelings.

According to Susanna, these psychological problems may also be related to sexual abuse suffered in transit countries that, in turn, may cause diseases or infections: 'Belonging to sexual minorities is an additional factor that generates a higher level of vulnerability. (...) These claimants appear to be more subject to sexual exploitation (...) especially those who are not able to hide their sexual orientation'. She provided the example of two men who, after arriving in Libya, were sold and raped before attempting to cross the Mediterranean Sea. As a consequence of sexual exploitation, the sole survivor who eventually arrived in Italy discovered that he was infected with HIV in Libya.

While only a few people felt sufficiently comfortable or secure to talk openly about their journey to Europe, and we avoided pushing them to do so because of the risk of re-traumatisation (Chap. 2), our data show that travel experiences varied according to the destination country. Lacking space to recount in full these experiences, we note that whereas the journeys of those arriving in Germany and Italy often involved smugglers, a significant number of journeys to the UK seemed connected to trafficking. For instance, Daphne (UK) said:

I was brought here by somebody called (...) and he promised me to find me a job here. But, when we reach here (...), the job he offered me was prostitution. That is why I ran away from him and (...) I went to claim asylum.

Experiences of direct flights were reported most often by participants in the UK, and were rare for our participants in Italy. Sometimes, those were the result of a 'fortunate' chain of events. For instance, Halim (Germany) remembered:

I didn't want to really leave but because of the threats I felt I had to, and around that time I got invited to a conference in Berlin and that was my visa out of Egypt and into Europe. (...) Somehow, it ended up being Berlin without me really planning to be in Berlin.

In her turn, Shany arrived in Germany because her job involved travel in Europe, while Mary and Zaro used their sporting achievements to secure invitation letters and apply for short-term visas to the UK. Others, like Veronica and Julia (Germany), fleeing Russia, used tourist visas, and yet others, like Fares (Germany), fleeing Syria, resorted to a student visa. In short, due to the lack of any systematic means of safe passage to Europe, SOGI claimants who flee are forced to use a range of ways to reach Europe and, only on arrival, submit applications for international protection. 
SOGI claimants in Germany and Italy had generally taken different routes, in line with more general migratory flows. ${ }^{6}$ In both cases, however, they were exposed en route, along with other people in need of international protection, to experiences of violence, extortion and abuse, as well as additional isolation. As Prince Emrah (Germany) recalled, '[t]alking is so difficult, not sleeping, not eating anything, sleeping with I don't know how many people, not counting. And I'm alone from Turkmenistan to Turkey. (...) I [could not] tell my feelings'.

Most of our asylum claimant participants in Germany followed the Balkan route, entering Europe by land via Eastern European countries. The length of some journeys was notable. While Tina took seven months to arrive to Germany via Greece, Bebars recalled his four-week travel from Syria to Germany: he went from Syria to Lebanon, Turkey, Greece, then he crossed Macedonia and Austria by train, bus, and on foot before he arrived in Germany. Sometimes the journey took even longer, as for those SOGI claimants fleeing sub-Saharan countries. For instance, a claimant who travelled to Germany from Uganda via Turkey, explained in detail:

The best way was to go to Kakuma Camp (...) to seek for asylum in Kenya. (...) It's where I met fellow Ugandans who are also LGBT people. Some had been there for one week and they told me life was hard there, the camp was full. (...) I had to fly out of Kenya. I went to Turkey (...) I stayed on the streets for almost one week and a half. (...) Life was really hard. (...) There was a gay man that I came to know. He took me to his place. (...) He gave me another choice of life. [But] he started treating me badly, really, really badly. He could sometimes even send some guys to force me to have sex with them, (...) they raped me, forced me to have it. [After meeting two Syrian guys] we collected some small money. (...) So I ended up with these guys on the journey, on the same journey, on a small boat from Turkey to Greece, to a certain island in Greece. When we entered Greece (...) they welcomed us, they took some small care of us (...) we were given some bad food. (...) After we were released and we (...) proceeded to Macedonia, from Macedonia we just passed through, we entered Serbia. (...) We entered Hungary. (...) They detained me in Hungary, [but] they released us, they drove us to the next border. (...) When we reached Vienna, at the Bahnhof [train station] there were so many people and we heard that the German borders are closed. (...) Then after some time they boarded us in (...) a train. And they brought us to Germany.

William (Germany) confirmed that the journey appears to be a chain of causal events, where forced labour and sexual exploitation is often the price for a passage to Europe:

I stayed with this man in this house surviving on the mercy of these people. (...) We went to a place called Izmir. (...) It's like, this was the place where people used to cross. (...) One day, we were crossing, we fell into the water and were rescued by the Turkish police, and they imprisoned us (...) they gave us some white papers, return. These papers were allowing us now to move. (...) When we crossed, we came to Greece. (...) It was a very big reception camp. (...) They took us to Athens. Now in Athens we slept on the street for two days in the city. Then we managed to board trains, which trains took us through Macedonia, they took us again to Serbia. In Serbia, we stayed there for two days again sleeping on the streets. Then (...) I reached Hungary. (...) I was not looking for good things to be in a good

\footnotetext{
${ }^{6}$ See Frontex: https://frontex.europa.eu/along-eu-borders/migratory-map/
} 
life, but I was looking for a place where my life could be safe. And I said, since I'm here I'm going to stay here. Let me make this my home.

Yet, the discriminatory treatment suffered in Hungary motivated him to move to Germany.

In the hope of avoiding such violent and traumatic experiences, some SOGI claimants feel forced to resort to fake visas. As Diana (Germany) explained:

I've heard a lot of disadvantages, that's a very difficult and dangerous way. That's why I said, okay, so I tried to find a direct route and I just want to go straight from Iran to that safe country. And that was - it costs more, but I found someone, there's just you pay and give you a fake visa. (...) I wanted to leave Iran because I could not live with the situation anymore. (...) My mother did not know that I go to Germany to claim asylum. She thought I have a tourist visa. I did not tell my family what would happen.

Most SOGI claimants interviewed in Italy, as nationals of sub-Saharan countries, arrived instead through the Mediterranean by sea. Ken explained his travel as follows: 'From Nigeria to Niger, from Niger to Algeria, from Algeria to Libya, then I got stopped in Libya for some time. Then from Libya to Italy [by boat]'. Dev and Fred, fleeing Cameroon, passed through Algeria, where they worked for five months, before reaching Libya. Mamaka had an even longer journey:

I am from the Gambia. (...) When I have the problem in my country I moved to Senegal because it was the neighbourest country (...) I was there for a year but it could not be ok with me. So (...) I came to Mali. So it is from Mali I had the information that there is a road going to Italy (...) from Mali to a placed called Niamey [in Niger] (...). Then from Niamey to Agadez [in Niger], from Agadez to Sabha [in Libya] (...) I was almost two to three weeks, almost a month in Libya before I took the boat to Italy.

Similar journeys were described by other participants, including Buba, Bella, Diarra, Franco, Siri and Moses. As Moses recalled, '[m]y intention (...) was to just leave my country and go to a place where I could probably be safe from the horrors of my country'. Instead, he ended up spending eight months in Libya before being able to cross the sea.

During this kind of journey, episodes of violence, detention and extortion were frequently reported. According to Gbona (Italy), who reached Libya from Mali through the desert, 'along the way, there were some Arabs, they are in the desert. They went around, around and then stopped us, forced [us] to get off the car, and start beating... yes, beating'. As Nelo (Italy) also explained:

Basically, I was just only run saving my life first, and when I got to Niger, to Libya, they were very angry because the money I was supposed to pay, I didn't pay... they have to keep me in different parts, called prison, they call it... kidnapping. (...) They will (...) beat you and tell you to call your people at home to send the money.

The lack of support from contacts in their country may lead to extended deprivation of one's liberty. So Odosa summarised his travel experience as follows: 'Oh, the travel. It is not good. (...) I spent close to six months (...) because of the delay and the kidnapping, the "trankey" [forced labour camp] in Libya. (...) From Nigeria to Italy, take like one month and some weeks, but because of the kind of problem I face along the road, that is why I use close to six months'. 
Nice Guy (focus group no. 1, northern Italy) remembered the attempt to cross the sea as an experience of complete uncertainty: 'All I knew was that, OK, the boat is going to take me to Europe, I don't even know if it's Italy, France, Germany... No way, I don't know. In fact, it's just like being re-born, you know nothing'. For this final part of the trip, other SOGI claimants, like Nelo, Gbona and Moses, expressed mixed feelings following incidents on the high sea and subsequent rescues by NGOs ('the Swedish', 'the Norwegian' or 'the Dutch') or Italian coastguard vessels. For Gbona, 'Italy saved my life (...) we were on danger on the high sea with water rising and [the boat] going down', whereas for Moses:

Seeing the sea alone is like death already, because (...) if anything should happen, there is no safety guarantee and so (...) I felt that, at least (...) I am going to be alive (...) when the rescue came. So I arrived in Italy [and said] "thank God, I still have a future ahead". (...) For a moment I was happy.

Nelo (Italy) explained that he discourages other people from coming to Europe to avoid such fear: 'The most scary part of it is when you're on top of the blue sea. (...) So that's what I'm always advising every day, "look, don't think of coming to Europe by land [and by sea], it's not good, it's dangerous"'. Nelo felt lucky to have arrived in Europe, but also said that 'due to the fact that I just came in, my head is still a mess'. This 'mess' can be insurmountable for people, such Alain A., who lost their partners in the high sea after the sinking of the dinghy used to cross the Mediterranean Sea. The short and long-term consequences of these traumatic experiences in terms of health appear self-evident (Chap. 9; Alessi et al. 2018).

From the above, it seems that belonging to a SOGI minority shaped our participants' journeys differently. On the one hand, it may influence the entire journey plan. For instance, Mary and Zaro (UK) explained that, in order to avoid raising suspicions, they travelled individually: 'First she... she went to Dubai, then I came, after three or four days I came, after her. Because we could not travel together'. On the other hand, SOGI aspects appear immaterial for some claimants, who see mere survival as their only need. According to Kennedy (Italy), who reached Libya from Nigeria, people simply hide their SOGI during the journey:

I stayed in Libya four months. (...) What you are just thinking at that particular moment is let me get to (...) a place to just rest my head. (...) The second thing is (...) food. When you eat, you begin to think security. When you get security, then your mind calms down [and] you express (...) feelings, you know, with person that you love.

Similarly, Alain A. (Italy) pointed out:

It is a very dangerous journey. For everyone, not only for LGBT, and it is not a journey where you get to know who is gay and who is not gay. Because it is just a journey, so we don't stay like to exhibit our characters, or our what we are. So, [in] my journey I didn't face a problem as an LGBT because I didn't identify myself as a LGBT.

For Ken (Italy), the reason to avoid mention of his SOGI was simply to avoid additional abuse: 'You don't talk about it, it is hell. No'. Yet, the negative effects of such repression and fear on the submission of the asylum claim at arrival are noticeable, as the next section will discuss. 
Finally, it is worth noting that a significant exception to these general trends seems to relate to those transgender claimants who were mostly nationals of South American countries and claimed asylum after several years in Italy. As Valentina, a social worker in Italy, explained: 'They have no other way to be granted a permit to stay in Italy. (...) Many sex workers from South America would not claim asylum but would like to work in Italy, as it happens in other European countries'. Valentina also reported that, where other transgender claimants from the same countries have travelled to Italy through Eastern European countries after flying to Russia, border authorities often signpost people to NGOs, more as a result of practice than clear guidance but with positive implications in terms of addressing their reception needs. In her view, this is related to the 'visibility' of trans claimants, which distinguishes them from other SOGI minorities.

From the above analysis, one of the most difficult aspects of such journeys is certainly the treatment suffered in transit countries. This has an additional impact on the well-being and social experiences at and post-arrival of SOGI claimants. The countries of transit for claimants headed to Europe are often Turkey and Libya, which are also the primary recipients of the EU and its member states' assistance to neighbouring countries in the area of migration irrespective of their human rights record (Human Rights Watch 2019; United Nations Support Mission in LibyaOffice of the High Commissioner for Human Rights 2018). In this respect, it is appropriate to explore, albeit briefly, how SOGI claimants experience and perceive these countries. Most importantly, the intersection of a variety of personal characteristics - being migrant and member of a SOGI minority - appears to render SOGI claimants more exposed to abuse in these transit countries than other migrants and refugees. This risk increases exponentially when they cannot leave these countries, or are even sent back to their countries of origin, especially as a consequence of EU-led externalisation migration policies (Liguori 2018).

Starting with Turkey, the prevalence of homophobia and transphobia that has been denounced at international level (Ramón Mendos 2019), combined with high levels of racism (UNHCR 2011), were confirmed by our participants. For instance, William (Germany), who arrived to Turkey from Uganda, explained:

\begin{abstract}
When I told [a Turkish man] that I'm gay he told me "that cannot happen. In Turkey I cannot even take you to the authorities because they cannot accept you". The next day he transferred me to another house. (...) He moved me out of his family, because he had two kids and a wife. (...) I stayed in fear, crying day and night, fearing the police because they could arrest me any time. (...) I could not work because I used to fear going to the streets. The Turkish people are not easy people. They are racists, they segregate Blacks, you're a Black man.
\end{abstract}

As for Libya, arbitrary detention is the rule for all people trying to migrate across the Mediterranean to reach Europe (MSF 2019; United Nations Support Mission in Libya-Office of the High Commissioner for Human Rights 2018). SOGI claimants communicated a striking level of fear at the prospect of being forced to stay in Libya. Despite the severity of the legal and social environment of his country of origin, Nelo (Italy) told us that: 'It's even better that you are recognised as a gay in 
Nigeria than to be recognised as a gay in Libya, in Arab country'. In his view, violence in Libya reaches unimaginable levels.

In an attempt to explain the negative implications of such journeys and treatment in transit countries, Just Me (focus group no. 3, northern Italy) pointed out: 'Many people that died in my presence (...) even in Libya (...) they kill somebody from my back. (...) You see people die after passing through all this, you come here, Commission give[s] you negative. (...) If you are not strong, you will go mad'. Yet, these traumatic stories and consequences in terms of depression and anxiety are rarely considered and addressed at and after arrival in host countries (Piwowarczyk et al. 2017).

As we will explore especially in Chap. 7, the circumstances of the departure, aspects of the journey and the treatment in transit countries may however be, among others, at the centre of the credibility assessment at administrative or judicial level. For instance, during a hearing, an Italian judge focused a significant part of the questioning on the separation of the claimant from his partner in Libya and on the attempts made, at arrival and in Libya, to obtain any information about his partner's disappearance (Tribunal observation, northern Italy 2018). The claimant argued that, at arrival, he was too traumatised to seek information about his partner's fate from Italian authorities or from his smugglers. Any empathy, which common sense should require, aside from any theoretical approach or SOGI guidelines (Chaps. 3 and 4), was replaced by an evident 'disbelief'. Similar episodes show that decisionmakers are not always aware of, or consciously ignore, the general condition of SOGI claimants on arrival in Europe and the reasons why they may not be able to express their SOGI immediately. The next section therefore aims to explore this particular aspect.

\subsection{The Arrival in Europe}

A complex mixture of feelings was shared by participants in relation to their arrival in Europe. Several asylum claimant participants described feelings of safety. This was true of Susan (focus group no. 3, Bavaria, Germany), who told us '[w]hen I came to Germany, I felt safe', as well as Silver (Italy), who said: 'When I arrived in Italy (...) I was very happy [and] I said "Why no one is looking at me? Why do not they beat me?"' Others remembered, instead, feeling fear and anxiety about the risk of being returned. As Miria (focus group no. 3, London, UK) explained: 'If it is going back to Uganda (...) I said I really tried to kill myself, I said, already in Uganda I was dead. Kill me here rather than spoiling your ticket'.

Related to their stressful experiences before and upon arrival, some SOGI claimants told stories of alcoholism and drug abuse. As Shany said: 'Mostly I wake up at six in the evening, but I was using a lot of marijuana, a lot of alcohol. (...) I [didn't] want to think nothing. (...) I [didn't] want to wake up because I just, like, think somebody in the door going to kill me. I was a paranoid'. 
Above all, a feeling of bewilderment emerged. As Nelo (Italy) explained: 'We don't know many things about asylum or whatever. I've been to Niger, I've been to Libya, I never had to go to the courts, go to Commission, go to anything in order to stay'. This feeling may have been exacerbated in cases of collective arrivals. As Vincenzo, an LGBTIQ+ group volunteer in Italy, pointed out: 'At arrival the security approach is undeniable nowadays. (...) People probably get the perception of being only numbers and are put under control'. In such situations, the SOGI dimension does not receive the attention and care it warrants.

In the particular context of arrival, participants consistently raised at least three issues to assess how fair an asylum system is for SOGI minorities: (1) whether, and what, information is provided on SOGI asylum at the moment of first contact with national authorities; (2) the guarantee of individual assessments; and (3) whether the initial reception (or detention) takes SOGI into account. Before delving into these aspects, a brief clarification is needed. First, our survey confirmed that arrival is a key moment for SOGI claimants themselves, as $63 \%$ of respondents claimed international protection immediately after they reached their host country. Second, the conditions of arrival clearly vary between Germany, Italy and UK. As discussed in Chap. 4, the reason for this lies not only in the lack of harmonisation between EU countries in this specific area, ${ }^{7}$ but also in geo-political factors that explain the different travel experiences of SOGI claimants arriving in these three countries (IOM 2019).

Regarding the general initial procedure, in Germany asylum applications can only be registered at the BAMF, but an asylum claimant can also report to a federal or local police, or at reception facilities (ECRE, AIDA \& Asyl und Migration 2019, p. 18). While this reporting should happen 'immediately', there is no time limit for lodging an application. The situation of SOGI claimants interviewed in Germany confirmed that the bulk of applications were registered at the BAMF, after having been sorted and processed at the border.

Italy, in turn, has faced a high number of arrivals in recent years. As a result, most people claiming asylum, including SOGI claimants, followed a similar path for the submission and subsequent evaluation of their asylum request. On arrival at the border, by land or by sea, Italian authorities take charge and, afterwards, claimants' asylum requests are registered at the police local headquarters ('Questura'). As Jonathan, an LGBTIQ+ group volunteer, explained, SOGI claimants who are already in Italy or enter the country in a different way have less chance of being taken in charge by the authorities. It may therefore be more difficult for these claimants to receive initial support, at least in terms of accommodation.

The UK, in contrast, has not faced similar high numbers of arrivals. Excluding specific programmes such as the Syrian Vulnerable Persons Resettlement Scheme, asylum applications should be made on arrival or 'at the earliest possible opportunity' (UKVI 2016, p. 4). This means that if claimants do not apply on arrival or at the border, as was the case for some of our participants, they submit their

\footnotetext{
${ }^{7}$ In contrast to other aspects of the asylum process, as the CEAS shows (Chaps. 4, 6, 7 and 8).
} 
application to offices 'in country', the most well-known being Lunar House in Croydon, South London. Once the application is submitted, a meeting with an immigration officer (known as a 'screening interview') takes place, followed by an asylum interview with a caseworker some time later (usually a few weeks, but sometimes months).

Taken this broad context into account, the situation that each SOGI claimant needs to face initially, including the nature of their first contact with authorities, varies in light of individual circumstances and according to the receiving country in question. Yet, from our data, some general trends emerge.

\subsubsection{Information on SOGI Asylum}

The importance of having knowledge on SOGI asylum to enable informed decisions is widely recognised. For instance, according to Jean, a member of the European Parliament, the access to 'quality information', which needs to be provided 'in a format they can understand', is essential in improving the system for (all) claimants. As Ibrahim (Germany) explained: 'I got informed a bit about asylum and I felt it more reasonable to stay and not be living in fear'.

Some SOGI claimants we met knew at the time of their arrival in Europe that they could make an application for protection on SOGI grounds. Such information is often shared through SOGI claimants and refugees already in Europe. For instance, Momo (Italy) explained that one of his friends in France instructed him: 'He explained me everything. You need to do this, follow this procedure, until you get international protection. In Africa you do not have such a thing [being protected on SOGI grounds]'. According to Jonathan, an LGBTIQ+ group volunteer in Italy, and Livio, a lawyer in Italy, the increasing exchange of information on SOGI asylum between potential claimants who are still in their countries of origin, asylum claimants (including SOGI), NGOs and other personal contacts in Europe, means there is a greater awareness of relevant procedures, which may on occasion also improve decision-making. A good example of this was provided by Kamel, who was granted refugee status in Italy after having prepared all the necessary material to support his claim before fleeing Libya. For these claimants, it may have been easier to tell their story at arrival. Wole (focus group no. 2, Glasgow, UK) explained: 'When I was back at home, I did a research and I found out that you can claim in the UK, so when I came in the UK, at the airport, I claimed directly for asylum protection'. Michael (UK) also recalled:

When I came to... airport Heathrow, I ask officer (...) please can you help me with protection. And they asked me a lot of questions about why you ask about protection, why we should help you with asylum, and I answer them everything.

However, this openness does not necessarily secure advantages in relation to individual assessments and reception conditions. To use Michael's experience as an example once again: 'After that I had been in airport I didn't know anyone in Great 
Britain (laughs) I didn't have any colleagues here, I didn't have any friends here'. He was eventually helped by an NGO.

Yet, most of our claimant participants identified the lack of information on SOGI asylum at arrival as one of the most problematic aspects of the system across Europe. According to our survey, $31 \%$ of respondents did not know they could claim asylum on SOGI grounds when they arrived. This lack of information not only prevents them requesting asylum on SOGI grounds as soon as possible, it also denies them reassurance that they are now safe if the reason for having fled their country is connected with their SOGI. As Ibrahim (Germany) confirmed, many SOGI refugees 'didn't know from the beginning that they can apply for asylum based on their sexual orientation'. This failure of communication may be expected given that the relevant legislation in Germany, Italy and the UK does not include a general duty to provide specific information on SOGI asylum at arrival, nor do relevant EU directives address this point. Yet, there is a general duty to inform claimants about the asylum procedure (for instance, Recitals 22 and 25 and Article 12 of the Procedures Directive), and its importance has been stressed also by the ECtHR in its jurisprudence. ${ }^{8}$ In some cases, specific information is provided thanks to the involvement of NGOs. For example, in the UK, in 2014, the Scottish Refugee Council (with other agencies) published an information leaflet for SOGI asylum claimants arriving in the UK in 12 community languages (Scottish Refugee Council 2014). However, this example of good practice has not been taken forward elsewhere. The 2019 reform in Germany (Chap. 4), which restricts the role of NGO counselling as it happens already in AnkER Centres (ECRE, AIDA 2019, pp. 10-11), may therefore have a particularly negative impact on the right to receive adequate information on SOGI asylum.

More generally, according to Helena, an EASO officer, even when SOGI information is provided, there is lack of uniformity across Europe. Therefore, it is not surprising that a significant number of our participants were unaware of what 'asylum' is and what procedures apply, in general, and that SOGI asylum is possible. Shany (Germany) explained:

Even the word asylum, I couldn't even find it in my mind in that time because I was like, you know, you using, this is like a big, big moment which like your brain is completely, it's not working, it's like plastic.

According to Gbona (Italy), at arrival, no one asked the reason why he fled his country of origin but only for basic personal details. Siri (Italy) became aware at arrival that he could apply for asylum in order not to be immediately returned to his country of origin, but no information on SOGI was provided to him. Giovanna, a lawyer who was involved as a volunteer in a few disembarkation operations, confirmed the way post-arrival situations are managed in Italy:

Actually, after the disembarkation, only a few general pieces of information are requested, such as age or health records. Then, they are sorted into groups and asked whether they want to apply for asylum. If they don't, a return order is issued. There is no room for

${ }^{8}$ M.A. and Others v. Lithuania, Application no. 59793/17, 12 December 2018. 
personal stories and, in that very particular moment, people just arrived have often no idea about refugee status, subsidiarity or humanitarian protection.

Participants in other countries, like the UK, shared similar experiences. Meggs, for example, explained:

I didn't know it was called asylum, no, I didn't know. I just, when I got here I thought, since I am here, that is it, I will just have to find a place to live legally, and start my life all over again (...). That is what I thought, I didn't know there was this process, and how long it is, and how painful it is, I wasn't ready and prepared for that.

Success (Germany), in turn, explained: 'I was not bold enough to say that. Yeah. I was not bold enough, because I thought it was like Nigeria'. This fear may increase when different personal and cultural factors intersect, as our theoretical approach suggests (Chap. 3). For instance, in terms of relationship with fellow nationals, Lutfor (UK) recalled:

No, I didn't hear anything about [being able to claim] the asylum and, being honest, when I was living with other guys [from Pakistan and India], I think they have no idea what is asylum (...) I didn't work, so I was living with them, I cooked for them, I ironed their clothes, cleaned the house (...) I was really scared to go out.

The difficulties faced by SOGI claimants are often aggravated by other elements. First, translation issues are a case in point. As Sadia (UK) stated:

But that time also I am not doing any claim because I, I have a problem, language problem. I am not educated, so I have a problem. So I didn't understand, I didn't understand, I am just going there and sitting, I don't understand anything.

Second, other than facing unknown bureaucratic challenges, feelings of distress may hamper the identification of SOGI as a reason for claiming asylum. For instance, Miria (UK) explained:

I had some problems. (...) Yes, I am a lesbian, but for that time I had no idea of that. And, you know, when you have a problem, you can't think about that thing at the same time, because I was struggling a lot. Yes, and my life was in danger, so when I came here I had to think about my life. Yes, I didn't think about of being a lesbian, I had to put that aside, because at that time that was not the issue. But, I was struggling.

The situation is even more complex when SOGI claimants are not identified by public authorities as soon as they arrive. For those who enter Europe in a group or are exploited after arrival obtaining accurate information about SOGI asylum can be particularly difficult. This trend is especially noticeable in the UK. Irma stated:

No, I never knew that [SOGI asylum], I never knew that. Because, I mean, I never had the opportunity to talk to people. Where who brought me into the country, I was under like security, the woman was all the time, she was saying "I will report you back, I will send you back.” (...) If I knew like that [SOGI asylum], I would have come out straight away with my sexuality.

Jayne, also an asylum claimant in the UK, explained:

I had to stay with people I met from church, and surprisingly throughout the years no one said anything to me about asylum. Maybe those people were taking advantage to have me in the house, maybe babysitting, just so that I have somewhere to live. 
A potential consequence of the lack of adequate information on SOGI asylum is the submission of a claim on grounds not related to SOGI (Chap. 7), but often connected to a particular situation of widespread violence in their country of origin. For instance, Fares (Germany), like other SOGI claimants, applied first on the basis of religious and political persecution due to the existence of political or religious conflicts. Likewise, Kennedy (Italy), fleeing Nigeria, explained:

I did not see reason to tell them that it's [because I'm] gay, because I don't want any problem again to reoccur, whereby I will be running from Italy again to another place. So that is the reason why I told them, yes, it's Boko Haram.

Damiano, a lawyer in Italy, and Valentina, a social worker in Italy, highlighted a particular concern for SOGI claimants: the combination of the lack of information about SOGI asylum, the lack of knowledge about the treatment of SOGI minorities in the host country, internalised homophobia and/or the proximity of fellow nationals may nudge some SOGI claimants to rely on more familiar narratives of persecution as the basis of their claim. This makes it more important that authorities are sensitive to what may be the real reasons for claiming asylum in the initial screening, as well as during the main interview (Chaps. 6 and 7).

Titti, a decision-maker in Italy, also stressed this point:

Let me give you an example. A claimant could say "I left my country because I was in conflict with my father" and, then, incidentally says that he left his [same-sex] "partner" in his country (...) This is a SOGI claim but he does not know that. (...) Probably, he does not have the tools to understand that the conflict with his father is based on his sexual orientation and that this is something wrong.

Without official information about SOGI asylum at the point of arrival, claimants had to rely on their own research or word-of-mouth information from other claimants. Alain A. (Italy) explained:

When I came to Italy, first of all I had so much fear in me, like the fear I brought from my country was still in me. Yes, I knew like Italy protected gay people or the homosexual, but I didn't know, like, where to deal with my problem, with who to speak to. So, I was so afraid and I went to the internet (...) to do research on gay associations.

For some SOGI claimants, however, having the relevant information did not guarantee a smooth process. For instance, Nelo (Italy) was still traumatised by his past experiences when he found out about the possibility of claiming asylum on SOGI grounds. He found it difficult to trust anyone: 'And when they said, I actually have to think of it, like trying to understand if this is just a trick'.

For other claimants, instead, discovering that SOGI minorities enjoy higher levels of social and legal protection in European countries, at least to a certain degree and on paper, was a source of relief and empowerment. As Miria (UK) pointed out:

When I saw people on the train free, for the first time to get that confidence, to know that lesbians are free here. (...) So, when I saw that I say what... oh this means LGBT here are free. Then my mind opened up, I started to know and I started to feel, what I am, to feel in my mind, I started to feel, feeling free. 
In this respect, refugee community organisations and support groups, which are often the first and trusted point of contact for newly arrived asylum claimants, play a positive role, although their support can be limited in this initial phase for reasons such as lack of resources or trained staff (Chap. 6). For example, Diarra (Italy) recalled that he was not aware of the possibility of requesting asylum on SOGI grounds but, thanks to an information session on SOGI rights organised by a support group in his reception centre, he learned how SOGI minorities are treated in Italy. As he put it: 'Today I can say that I'm gay. After that meeting, I went to talk to the reception centre's staff'. This feeling of empowerment was also experienced by those claimants who were already aware that they could submit an asylum request on SOGI grounds and needed a safe environment to be able to gradually open up about themselves. As Ophelie (focus group no. 2, Glasgow, UK) confirmed:

I did a research back home in Namibia so (...) I knew that you can claim asylum in Scotland. (...) The airport (...) was hectic, they didn't want to let us in and we (...) told them that "no, we can't go back because of my sexuality, I came with my partner". (...) [Scotland] is not an environment that we were used to, so we didn't, we were not open to show out our sexuality, because we were afraid of the same judgement we had home. (...) We had to hide (...) just stay indoors [and] not going out, until we met the LGBT Unity group. (...) It was fine, we were welcomed nicely.

To summarise, the lack of information on SOGI asylum and treatment of SOGI minorities before and at arrival may play a significant role in the submission of a claim in terms of content, timing and evidence. Surprisingly, as we will explore in Chap. 7, the lack of awareness of SOGI asylum is not duly considered by decisionmakers, who sometimes also use it to cast doubt on SOGI claimants' credibility. The fallaciousness of such an approach was strongly criticised by Emily, a decisionmaker in the UK:

[Most people know they can claim on that basis] more now than before. We're seeing a lot more LGBT cases than ever before. [Decision-makers may ask] "if you've been here for 15 years, why have you never claimed asylum?" (...) I don't think I knew before this job that that is actually a specific reason for claiming asylum in this country, I've lived here for 28 years and I didn't know that!

As Giulia, an LGBTIQ+ group volunteer in Italy, stated: 'SOGI is not considered until there is a need to express it'. This need may arise during the initial individual assessment.

\subsubsection{Initial Screenings}

When a claimant receives appropriate information, the initial screening is more likely to run smoothly. For instance, Siri (Italy) remembered that, after he had disembarked, he was told simply that everyone in Italy is free to say whatever they want, as long as they are not breaking the law. As he explained: 'I was not told that I could be homosexual here. [But] when I was sent to Questura [police local headquarters] after 15 days and I was asked the reasons why I fled my country, I did not 
hesitate'. When this sort of reassurance about speaking openly is not provided to claimants, it is more difficult for SOGI claimants to share their real stories at the first screening interview. The same is true when a strong securitisation approach is adopted at arrival, echoing the security paradigm that has characterised EU policies since Amsterdam (Kostakopoulou 2000). For instance, Mamaka (Italy) remembered that she was only fingerprinted, while no immediate access to an immigration office was granted. Again in Italy, another participant recalled that, despite her willing to share her story, only examinations of a medical nature were carried out at arrival:

I told them that I was being raped and all, so they took me to one place, they snapped my picture and they took me to the hospital, check if I am pregnant, they found out that I was pregnant. (...) They put us on one big bus, so we spent almost a full day on the road. (...) The next day (...) they took me to Questura.

Although the duty of individual and objective assessment of all international protection claims is well established in ECHR ${ }^{9}$ and EU law (EASO 2018), there were no accounts of any SOGI-friendly individual assessment at national level during the screening interview stage. The different logistics in each country also need to be considered. Whereas in all three countries under investigation the initial screening is carried out by national officers, in Germany and Italy it may take place in arrival/reception centres. No clear or direct questions on SOGI are asked at this stage, unless claimants self-identify as LGBTIQ+, as confirmed by our data. Taking the example of Italy, when a request is submitted to the police local headquarters ('Questura'), only general information is required: personal details, the presence of any family members in Europe, educational and family background, and travel details. While the form used for screening - the so-called 'C3' - expressly asks about the reasons for applying for international protection, these reasons are often not specified at this stage (Chap. 6).

The difficulty in talking about individual personal experiences in terms of SOGI was confirmed by other participants. For example, SOGI was not mentioned during these initial stages in the cases of Pato and Frank (focus group no. 3, northern Italy), Osa and Chima (focus group no. 4, northern Italy) or Bakary (focus group no. 2, northern Italy), who were hosted in temporary camps in southern Italy for a few days. However, it should be noted that for some people this was not an issue, because not addressing SOGI as soon as possible may be more consistent with a sensitive cultural-based approach. According to Jonathan, an LGBTIQ+ group volunteer:

We have a very Western approach to this aspect (...). Many people can be MSM [men who have sex with men] or have adopted a similar behaviour (...) and, if you are asked "are you gay?", they might not answer "yes". I think it's a positive thing that it's not specified at this stage.

Whether or not such an approach should be followed as a rule is doubtful, individualised solutions being more appropriate to balance all general and personal factors at play. The perception of this initial stage of the asylum procedure shared by

\footnotetext{
${ }^{9}$ For example, Sharifi and Others v. Italy and Greece, Application no. 16643/09, 21 October 2014.
} 
Nice Guy (focus group no. 1, northern Italy), who was asked to explain the reasons why he fled Nigeria after the arrival in a reception centre, offers a good overview:

\begin{abstract}
We come here the first time, as asylum seekers, we know nothing about the Italian system or anything. Then, like just I think within a week they gave us piece of paper to fill with our data and everything about our stories. A lot of us do not even know what we are writing. Some are still sick, very, very sick, they have other people write it for them. Some have other people advise them, ah don't write this, write this, and it is not right. They make blunders, big mistake. (...) Then they submit it, without nobody educating them about the concept of the form they are filling. (...) You cannot even get a copy of that form - you have just few days to submit it, and that's this. (...) They photostated [photocopied] the form (...) "go and write your story, go and write" (...) What can you write? (...) Then later, you start judging the same person by what the person wrote when his or her head was not in a stable state. It's not good. They should encourage them and inform them the minute they get here. Give them time to understand. Let them ask questions also.
\end{abstract}

This personal analysis of the shortcomings of this initial stage is enlightening. In addition to the lack of appropriate information on asylum (in general and specifically in relation to SOGI) and the delicate mental and physical condition of claimants, the importance of a number of other factors emerges strongly: the lack of support; the short time period between arrival and first screening; the level of education of claimants; the influence of other people claiming asylum on the grounds for persecution that are put forward; and the risk of authorities using the initial screening as the basis for denying international protection.

The lack of support received on arrival was indeed stressed by participants in all countries. Starting with Germany, Trudy Ann remembered when she arrived in Frankfurt with her girlfriend and they said at the airport that they were a samesex couple:

When we just arrived off the plane and go to the immigration part, we told the lady that we wanted to seek asylum. She was shocked at first (...) like she never know what we were speaking about. So I had to repeat it back three times.

The support in arrival or reception centres may also be problematic when SOGI is not taken into account. For instance, Jacqueline (Germany) explained: 'Generally in the camps they don't ask about your sexual preference or the reason why you came. That is saved for the big day [main interview]'. This lack of SOGI support played a bigger role in Italy where SOGI claimants' accounts are collected in reception centres, shortly after arrival. Silvana, a judge, and Valentina, a social worker, stressed that the staff of these centres are not adequately trained to explain to claimants that they can request asylum on SOGI grounds, or to identify such claims when individual stories are recorded (Chap. 6). Nelo, who shared his story only three months after arrival, pointed out that when he met trained and experienced staff in SOGI claims, it was not necessary for him to open up directly to be understood. As he told us:

When they collected my story for the first time, I gave them part of it (...) when I was in the hotel [reception centre], I asked them not to go to Nigerians. (...) Specific[ally], I said, I don't want to go to Nigerians. 
Because the staff at this point identified a potential SOGI claim on the basis of Nelo's plea, he eventually opened up about his reasons for fleeing Nigeria. Unfortunately, as we will explore in Chap. 6, staff in accommodation centres who are called upon to support asylum claimants in their claims procedure more often than not lack this ability to identify not-declared claims, being unprepared to deal with SOGI claims and, more generally, with people survivors of sexual and genderbased violence (UNHCR 2012b).

The level of education and how articulate claimants are, as well as the presence of other people from the same community, were also raised as important factors, which relevant authorities more often than not overlooked. As Ibrahim (Germany) put it: 'I am able, like I have a power of discussion and I have a power of communication with people. I can speak, or I know what I speak. But some other people don't know what to say'. When this 'power' is absent, other asylum claimants may play a significant part in SOGI claimants' narratives: Bakary (focus group no. 2, northern Italy) provided an example: 'When I arrived, I was given two papers. One for my personal details and the other for describing my personal history. (...) I asked a guy from Ghana how I should fill it'. In turn, Abdoul (focus group no. 2, northern Italy) found it difficult to give his account in the presence of other claimants with a similar cultural background:

When we arrived (...) after three or four days, I was given a few forms for describing my story. (...) Frankly (...) there was a big community of people from the Ivory Coast. (...) When they know that you are gay... no, I couldn't.

In this initial phase, there were few mechanisms signposting SOGI claimants to relevant NGOs or support groups, or addressing the specific needs of transgender claimants. Whereas a few of our participants referred to the fact that some reception centre staff suggested SOGI claimants contact support groups, only Valentina, a social worker in Italy, pointed out that national authorities at the north-eastern border of Italy seem to routinely signal the arrival of transgender people to NGOs and specialised support groups. The potential empowerment of SOGI claimants through contacts with LGBTIQ+ actors is therefore far from being facilitated in all countries under comparison.

The lack of specific solutions and support for trans claimants, including in terms of health (Chap. 9), is combined with bad practices at the initial screening. As Kamel (Italy) recalled:

I was asked if I was a boy or a girl. My documents, including my passport, signal that I am a woman, but I show myself as a man. I answered "I am trans", but [the officer] did not know what that means. (...) It was very bad. (...) I submitted my request, I was given a form (...) and then stop. I went out and I spent my days in the streets, without a doctor, hormones, nothing.

What is more, apart from a few exceptions, the initial screening appears to play no role in identifying appropriate accommodation in any country studied. There is no consideration of the need to provide queer spaces, where SOGI claimants can be free from repetitive heterosexual performances (Chap. 3). The suggestion given to Julian (focus group no. 5, Bavaria, Germany) by an officer is illustrative of the 
obligation imposed on asylum claimants to cope with non-queer spaces by erasing their SOGI:

The first office I went to was the Bundesamt [federal office] in Bielefeld, that's where my asylum process started from. (...) And the first person who interviewed me, when (...) I explained to her the reason I don't want to go back home is because I'm a lesbian and I'm having so many issues at home. She did the paperwork for me to be transferred to Munich and she told me not to say it to anybody in those camps. Meaning, she was aware more than me that it could also be dangerous for me.

In light of this omission, we now consider how SOGI claimants are initially hosted in the countries under investigation.

\subsubsection{Initial Reception and Detention}

The EU Reception Directive omits any reference to SOGI (Ferreira 2018). Therefore, as further explored in Chap. 8, it is not surprising that no country involved in this research has any specific policy in place for the initial reception of those who identify as SOGI claimants. This lack of specific regulations or provision gives rise to a range of experiences that, more often than not, leave SOGI asylum claimants in 'vulnerable' situations at arrival. In light of the wide use of detention measures in the UK in comparison to Germany (at least until the 2019 reform, Chap. 4) and Italy, this lack of specificity does not relate only to reception centres but applies also to detention structures. While in Germany a threefold system of reception is in place (Chap. 8), Italy has shaped its system on the basis of an emergency rationale owing to collective migration flows and, more recently, to far-right political policies (ECRE, AIDA \& ASGI 2019).

This state of affairs was confirmed by our participants. In most cases, SOGI played no role in the allocation of accommodation or reception conditions. For instance, Jacqueline (Germany), stressed that initial accommodation was chosen on the basis of her country of origin:

They had something like a temporary camp, so I stayed there like, almost a week. And then we went to the police, they took... that's when they asked our names and then they took the fingerprints, and that's where they were selecting where you're supposed to go depending on your country. Like, where you're coming from. So, I was given a ticket to come to Munich with all the directions. That's how I ended up here. (...) They don't ask why you came or anything, it's about placing you somewhere and then other things will follow.

This signals a wider trend in Germany, which is based on a distribution system called 'EASY' (Chap. 8), given that Amis (focus group no. 2, Bavaria) also stated that most claimants from Uganda are transferred to Munich. The risk of placing claimants in the same persecutory environment from which they have fled is therefore very high. A less organised approach is identifiable in Italy, as Moses pointed out: 
Moses: Initially, when we came it was a general camp. A big camp where there were up to like from 100, 150, a very big camp.

Interviewer: And did the authorities ask you "do you want to stay with people from your country or do you want to stay with other people"?

Moses: No, it was just normal distribution.

Yet, this 'normal distribution' - no matter on which basis it is carried out - does not reflect SOGI claimants' needs. In fact, by totally denying queer spaces, for SOGI claimants this initial accommodation was far from ideal. According to William (focus group no. 2, Bavaria, Germany): 'I was living with people that are not of my character, and anything maybe could happen to me. And I had stress, because of it not being open and always being in bed in that camp'. Equally, Jolly (focus group. no. 3, Bavaria, Germany) stressed:

I felt some difficulties in me. As in, how to identify myself. Why? First of all I looked around, there were not only the White people around. My fellow Blacks were also there. So, I didn't know their background or where they came from, and I had a fear that maybe some of them came from my country, whereby they know maybe me. (...) So, that was really a very big fear in me and it really made me not open up as fast as possible. Until when I went for the interview.

These fears connected to entirely heteronormative spaces have to be added to the precarious conditions of these initial reception centres. As Sandra (Germany) pointed out:

Then I got the shock of my life because that was a very huge place, where I was taken to. It was a big hall and there's were all kinds of people, all ages and all sexes. Kids, old, young, female, male, like, we're all there.

To make matters worse, what is intended as initial or provisional accommodation may end up as a long-term solution, coupled with restrictions on individual freedom of movement, something that, for instance, the 2019 reform in Germany further promoted by extending the length of stay in initial reception centres (Chap. 8). Ibrahim (Germany) explained:

There was a lot of isolation in the beginning. Part of it is about moving to another place where I didn't know people and I had to start from the beginning. Part of it is frustration... the first three months, for example, I'm not allowed to leave Berlin. That was a rule, and it sounded very strange for me. It just sounded very absurd and medieval.

Although the limited contacts established in these initial camps may help in finding out about LGBTIQ+ associations and support groups (for instance, Bella, Italy), a feeling of isolation often prevailed. According to Sandra (Germany):

We were just coexisting, nobody speaks to anyone, nobody tells anyone why they are fleeing, you just try to exist. (...) I felt empty, defeated, lost, tired, very, very tired. I lost all the motivation and all the thinkings that I had about life and what I wanted to achieve and everything. I was pretty much not thinking, my mind was just blank. I'm just sleeping and waking up not thinking about anything.

Edoardo (focus group no. 3, northern Italy) also recalled: 
I am a little boy and to the place they took me to in the camp was bush, and... meeting new people and I don't know. I don't know how they behave, I don't know how they talk, I was like, early morning someone would come to, "come, you don't talk, you don't eat, you don't do this", I was like, many times because what I saw in the sea was in my head, I don't know how to talk it, because it is like my spirits have left, I am trying to recover myself. Like one month, so I was in the room all alone.

This feeling of isolation was aggravated by the often inadequate management of these centres, as we explore in greater detail in Chap. 8. Just Me (focus group no. 3, northern Italy) worried about this:

I was afraid. I was solely scared because I was like in a strange place. Nobody, no family, I never knew anybody. I was just all alone. I was transferred from Messina to Settimo Torinese after about two weeks, I was taken to Saluggia, so the condition in the camp was so grim, so horrible. They don't really care about us, anyway. (...) Due to my experience in the sea and the road to Libya, I was in kind of depression. So, the camp nurse take me to a psychiatric to have a look at me and see if they could help about my situation.

In turn, Halim (Germany) explained:

It was very hard for me to...I mean, in the beginning, arriving there, I didn't really know if I felt safe to disclose that I'm gay to people even who were there. Because there was no introduction, guidance, orientation or... it was just, you discover things yourself. And I had a flatmate and basically I didn't want to tell anybody, even the workers, because if it comes out I might be at risk, and I don't want people to be talking about me, people might harass me or whatever. (...) And then I had the problems inside also, not feeling safe, also tired and not having my own private space. That was the biggest problem.

A range of experiences were shared in the UK. As many of our UK claimant participants arrived through a variety of channels, often with the help of third parties, and did not immediately claim asylum, their initial reception often had a private dimension. In these cases, a set of different actors came into play. For instance, Luc explained that:

I start[ed] living with the man (...) with hope that he will help me, but I [didn't] know anything about asylum and they told me I should not tell anyone about my life. (...) One day when I know he is not around, I went to the one church in London. (...) I was living in that church (...) so I started working [there].

The religious nature of this support, however, inhibited him from being himself: 'Since then, I [didn't] want to tell anyone about who I am'. However, without such support, individuals may be left entirely alone. As Mary and Zaro said: 'We were homeless, we did not know if you come to airport you can call to the police (...) we are not that quick'.

While detention did not emerge as an issue in Germany or Italy, it was of great concern in the UK, where calls to address the needs of sexual minorities in detention have remained mostly unaddressed (Chaps. 4 and 8). What is more, when deciding to detain SOGI claimants, asylum authorities do not place enough weight on previous long stays and the degree of social integration those claimants may already have achieved. For instance, SGW (focus group no. 4, London), an asylum claimant who arrived in the UK as a student, explained: 
After spending (...) six years out [in terms of sexuality] (...) I decided I didn't want to go back to Jamaica because I had adapted so much to the (...) culture (...). I told the Home Office (...) I went down to Croydon, in person, to (...) state my situation, and then I was detained in Yarlswood for about six weeks. (...) It was a miracle that through Asylum Aid (...) I was able to get temporary release.

Lutfor (UK) elucidated:

When I was in relationship, my boyfriend told me (...) that you can claim asylum based on your sexuality. (...) I didn't do any research or anything on any lawyer, I went, I make appointment to the Home Office, and I called them and I went for interview and they put me in detention for 22 days and I got a lawyer from legal aid, and interviewed and so that time I realised I should prepare for my case. I mean, I had the confidence that I am gay, I know this, so it would be easy to prove this. But I didn't know the system was too horrible.

Given the likelihood that SOGI minorities in detention may not feel able to disclose their SOGI as the basis for their asylum claim, it is particularly likely that their claims will also be jeopardised by relying on hearsay from other detainees, misinformation from detention centre staff with no training in RSD matters, and a lack of access to external sources of advice and information (as described in Chap. 4).

A final specific concern relates to people claiming asylum on gender identity grounds, where the lack of initial appropriate accommodation may be a serious obstacle to providing adequate support. Valentina, a social worker in Italy, recalled the case of a transgender claimant fleeing Cuba who arrived at the north-eastern Italian border: 'In that territory, all reception centres are reserved to men. They found for her an apartment managed by the Italian Red Cross. But it was absolutely personalised. There is no system in place, no reception protocols in this case'. Another transgender claimant, also remembered by Valentina, was less lucky on arrival in Tuscany, after having transited through Hungary and Austria: she was abandoned by the authorities, who failed to offer her any accommodation at all. The personal experience of Kamel, a transgender person claiming asylum in Italy, confirms the inadequacy of provision:

They told me that it was difficult, they did not know where to put me, if in a male or female reception centre, because I've not undergone the operation yet. We went to Caritas, in many churches, but no one hosted me (...) until an association called me and said that a family could host me. (...) Now they are my family (...) I stayed at their place during the first two weeks.

The above experiences make it clear that domestic authorities still fall short in meeting the duty to consider the individual's condition in order to identify the most appropriate reception solution on arrival, as required by ECtHR jurisprudence. ${ }^{10}$ Action, including specific amendments to the Reception Directive currently in force, seems more urgent than ever.

${ }^{10}$ O.M. v. Hungary, Application no. 9912/15, 5 July 2016, para. 53. 


\subsection{Concluding Remarks}

This chapter has shown that the difficulties experienced by SOGI claimants start well before the evaluation of their asylum request, and have clear implications for the submission of an asylum application on SOGI grounds. Considering the limited literature dealing with these aspects, this analysis brought new insights and depth to our current understanding of SOGI claimants' legal and social experiences in their countries of origin, during their journeys, and at their arrival.

In many cases, the need to escape persecution forces SOGI claimants to leave their countries of origin and travel taking unknown routes, often at very short or no notice. This experience is often accompanied by the fear that one can never go back. Within a very short period of time, the new "unknown" takes the place of an entire life and all that one has experienced matters only insofar as it supports or undermines the claim. Yet, while persecution is an essential reason for flight, it is still only a fragment of a larger, fuller more complex life made up of many experiences. Persecution does not define the individual, although the assumption that it does is prevalent and unspoken during the assessment of the claim, as the subsequent chapters will show.

This is also why Marhoon, who submitted a sur place claim (Battjes 2013; UNHCR, 2012a, para. 57), said: 'I [was] very afraid of applying for asylum because (...) I'd seen a lot of terrible pictures and heard news about refugee camps and what's going on there'. He therefore tried other options, including scholarship applications, before reluctantly taking the asylum pathway. Making a related point, Anna, an LGBTIQ+ group volunteer in Italy, recalled the case of a bi-national couple where the Russian national did not want to apply for asylum because he knew that, if refugee status was granted, he would not be able to go back to his country and see his family again. As a consequence, he preferred to try other strategies to secure protection, such as entering into a civil union with a Syrian refugee in Italy. Fear of loss may therefore prevail over international protection needs.

Within European asylum systems as currently conceived, claimants' experiences are homogenised and individual needs and fears are not taken into account. The lack of alternatives to asylum is itself a major problem needing further investigation. As pointed out by Diego and Riccardo, LGBTIQ+ group volunteers in Italy:

Why is it not possible to create humanitarian corridors? Why should they be forced to arrive in Italy to claim asylum? [We] have just received an e-mail from (...) a Sierra Leone's national, "how could I claim asylum in Italy?" (...) In this case, we can do almost nothing.

In this respect, the SOGI dimension of human corridors and the UNHCR's role in supporting these initiatives, as reported by Cristina (UNHCR officer, Italy), should be strengthened, and the possibility of issuing humanitarian visas considered. While a motion in this respect was adopted by the European Parliament, asking the Commission to prepare a draft for an EU regulation on humanitarian visas, thus bringing this matter under EU law with the consequent application of the EU 
Charter of Fundamental Rights, ${ }^{11}$ developments remain dependent on the political agenda of EU's member states too often based on their border control interests (Balboni and Danisi 2019).

Overall, the detrimental effects of their journeys on SOGI claimants are striking. As Just Me (focus group no. 3, northern Italy) stated:

If I have the freedom in my country, I don't think I will risk all the odd[s] to pass through the desert, to the sea, to Italy. So even to the European country that I can't speak their language. It is very difficult for me. Where I have nobody, it is like, if the life in my country was not so difficult about homosexual, I don't have to, I can't even imagine to take such risk.

Sometimes, such risk is undertaken for meeting basic survival needs, while totally ignoring the socio-cultural conditions of the chosen destination country. Nelo's experience (Italy) is a case in point:

I feel lucky, very, very lucky because... I spent three days or four days in the desert. (...) Some of them died in the process. (...) When you are fighting with the Arabs (...) they see you like, like an animal. (...) I heard a lot of stories that in Libya there's a lot of opportunity to work. (...) The plan was not to come to Europe.

The difficulties we have discussed above relating to submission of SOGI claims at arrival, often owing to the lack of appropriate information and inadequate initial screening, were highlighted as a key concern. As Giovanna, a lawyer in Italy put it:

The low percentage of SOGI claims and the fact that SOGI claimants are reluctant to manifest their personality, as well as the fact that they travelled to reach Europe, are all elements which should be clear enough to understand that, before submitting an asylum request, SOGI claimants really struggle with themselves.

The lack of a 'common language' preventing SOGI claimants from submitting their claims as soon as possible was expertly summarised by Valentina, a social worker in Italy:

We should help these people to create a vocabulary, their vocabulary. They have never told themselves to anyone. I can see a comparison with the Italian trans community, with the European trans community and the north America's trans community, where no words existed to narrate oneself.

The 'trans' dimension, which still remains largely unexplored, thus brings specific difficulties, compounded by the absence of appropriate initial accommodation.

More generally, the current initial reception solutions are inadequate to address SOGI claimants' needs. As they stand now, initial reception centres often contribute to aggravating individual fears on arrival, hampering the likelihood that a full and frank claim for asylum will be made at the earliest possible opportunity. One solution may be to classify SOGI claimants as 'vulnerable', as Gisela, a lawyer in Germany, and several other participants suggested:

[if] people [are] classified as a vulnerable group from the beginning, then they could be offered the corresponding information. Then maybe they would know before the interview

\footnotetext{
${ }^{11}$ European Parliament, Humanitarian Visas, 12 December 2018, 2018/2271(INL).
} 
that they do not have to be afraid, that it is not punishable in Germany, that the interpreters actually should not talk about it.

Whether or not this classification would improve the life experience of SOGI claimants at arrival, as explored in Chaps. 3 and 4, is still debatable. It is instead certain that different factors influence their experience, thus confirming the need to elaborate specific solutions for SOGI asylum, both before and upon arrival, based on an intersectional and queer human rights approach (Chap. 11). The urgency of addressing SOGI-specific needs is indeed apparent also in the context of the procedures in place for the evaluation of SOGI asylum applications, which we explore in the next chapter.

\section{References}

Alessi, E. J., Kahn, S., Woolner, L., \& Van Der Horn, R. (2018). Traumatic stress among sexual and gender minority refugees from the Middle East, North Africa, and Asia who fled to the European Union. Journal of Traumatic Stress, 31(6), 805-815.

Atak, I., Nakache, D., Guild, E., \& Crépeau, F. (2018). 'Migrants in vulnerable situations' and the global compact for safe orderly and regular migration (Queen Mary School of Law Legal Studies Research Paper No. 273/2018).

Balboni, M., \& Danisi, C. (2019). Human Rights and EU External Policy: In Search of Unity. In Various (Eds.), Liber Amicorum Angelo Davi. La vita giuridica internazionale nell'età della globalizzazione (pp. 374-410). Napoli: Editoriale Scientifica.

Battjes, H. (2013). Accommodation: Sur place claims and the accommodation requirement. In T. Spijkerboer (Ed.), Fleeing homophobia: Sexual orientation, gender identity and asylum. London: Routledge.

Camminga, B. (2018). "Gender refugees" in South Africa: The "common-sense" paradox. Africa Spectrum, 53(1), 89-112.

Camminga, B. (2019). Transgender refugees and the imagined South Africa: Bodies over borders and borders over bodies. Cham: Palgrave Macmillan. https://doi.org/10.1007/978-3-319-92669-8

Danisi, C. (2018). What 'safe harbours' are there for sexual orientation and gender identity asylum claims? A human rights reading of international law of the sea and refugee law. GenIUS Rivista di studi giuridici sull'orientamento sessuale e l'identità di genere, 5(2), 9-24.

Danisi, C. (2019). Crossing borders between international refugee law and international human rights law in the European context: Can human rights enhance protection against persecution based on sexual orientation (and beyond)? Netherlands Quarterly of Human Rights, 37(4), 359-378.

Del Guercio, A. (2018). Quali garanzie per il diritto all'unità familiare dei richiedenti e dei beneficiari di protezione internazionale con coniuge/partner dello stesso sesso? GenIUS - Rivista di studi giuridici sull'orientamento sessuale e l'identità di genere, 5(2), 59-73.

EASO - European Asylum Support Office. (2018). EASO practical guide: Qualification for international protection. Luxembourg: EASO.

ECRE - European Council on Refugees and Exiles, AIDA - Asylum Information Database. (2019). The AnkER centres. Implications for asylum procedures, reception and return. https:// www.asylumineurope.org/sites/default/files/anker_centres_report.pdf

ECRE - European Council on Refugees and Exiles, AIDA - Asylum Information Database, \& ASGI. (2019). National country report: Italy, 2018 update. ECRE - European Council on Refugees and Exiles. http://www.asylumineurope.org/sites/default/files/report-download/ aida_it_2018update.pdf 
ECRE - European Council on Refugees and Exiles, AIDA - Asylum Information Database, \& Asyl und Migration. (2019). National country report: Germany, 2018 update. ECRE - European Council on Refugees and Exiles. https://www.asylumineurope.org/sites/default/files/reportdownload/aida_de_2018update.pdf

Ferreira, N. (2018). Reforming the common European asylum system: Enough rainbow for queer asylum seekers? GenIUS - Rivista di studi giuridici sull'orientamento sessuale e l'identità di genere, 5(2), 25-42.

Giametta, C. (2016). Narrativizing one's sexuality/gender: Neoliberal humanitarianism and the right of asylum. In F. Stella, Y. Taylor, T. Reynolds, \& A. Rogers (Eds.), Sexuality, citizenship and belonging: Trans-national and intersectional perspectives. New York: Routledge.

House of Commons Canada. (2017). LGBTQ+ at risk abroad: Canada's call to action: Report of the standing committee on citizenship and immigration. Ottawa: House of Commons Canada.

HRW - Human Rights Watch. (2019). No escape from hell. https://www.hrw.org/sites/default/files/ report_pdf/eu0119_web2.pdf

IOM - International Organization for Migration. (2019). Flow monitoring - Europe. https://migration.iom.int/europe?type=arrivals

Kostakopoulou, T. (2000). The 'protective union'; change and continuity in migration law and policy in Post-Amsterdam Europe. JCMS: Journal of Common Market Studies, 38(3), 497-518. https://doi.org/10.1111/1468-5965.00232

Liguori, A. (2018). Migration law and the externalization of border controls: European state responsibility. New York: Routledge.

Moreno-Lax, V. (2018). Accessing asylum in Europe. Oxford: Oxford University Press.

MSF - Médecins Sans Frontières. (2019). Out of sight, out of mind: Refugees in Libya's detention centres. https://www.msf.org/out-sight-out-mind-refugees-libyas-detention-centres-libya

Munir, L. P. (2019). Fleeing gender: Reasons for displacement in Pakistan's transgender community. In A. Güler, M. Shevtsova, \& D. Venturi (Eds.), LGBTI asylum seekers and refugees from a legal and political perspective (pp. 49-70). Cham: Springer.

Odlum, A. (2019). To stay or to go? Decision-making of LGBTQI Syrians in mixed migration flows. In A. Güler, M. Shevtsova, \& D. Venturi (Eds.), LGBTI asylum seekers and refugees from a legal and political perspective (pp. 71-94). Cham: Springer.

Piwowarczyk, L., Fernandez, P., \& Sharma, A. (2017). Seeking asylum: Challenges faced by the LGB community. Journal of Immigrant and Minority Health, 19(3), 723-732. https://doi. org/10.1007/s10903-016-0363-9

Ramón Mendos, L. (2019). State-sponsored homophobia 2019: Global legislation overview update. ILGA. https://ilga.org/downloads/ILGA_World_State_Sponsored_Homophobia_ report_global_legislation_overview_update_December_2019.pdf

Scott FitzGerald, D. (2019). Refuge beyond reach: How rich democracies repel asylum seekers. New York: Oxford University Press.

Scottish Refugee Council. (2014). Asylum in the UK information for Lesbian, Gay, Bisexual, Transgender and Intersex (LGBTI) people. Scottish Refugee Council.

Türk, V. (2018). Promise and potential of the global compact on Refugees. International Journal of Refugee Law, 30(4), 575-583.

UKVI - UK Visas and Immigration. (2016). Information about your asylum application. https:// assets.publishing.service.gov.uk/government/uploads/system/uploads/attachment_data/ file/513585/Point_of_Claim_English_20160401.pdf

UN. (2017). International migration report. https://www.un.org/en/development/desa/population/ migration/publications/migrationreport/docs/MigrationReport2017_Highlights.pdf

UN Independent Expert on protection against violence and discrimination based on sexual orientation and gender identity. (2019). UN rights experts urge more protection for LGBTI refugees. https://www.ohchr.org/EN/NewsEvents/Pages/DisplayNews.aspx?NewsID=2476 4\&LangID=E 
UNHCR - UN High Commissioner for Refugees. (2011). Unsafe haven: The security challenges facing lesbian, gay, bisexual and transgender asylum seekers and refugees in Turkey (Updated edition) . Refworld. http://www.refworld.org/docid/524c114f4.html

UNHCR - UN High Commissioner for Refugees. (2012a). Guidelines on International Protection No. 9: Claims to Refugee Status based on Sexual Orientation and/or Gender Identity within the context of Article 1A(2) of the 1951 Convention and/or its 1967 Protocol relating to the Status of Refugees (HCR/GIP/12/09). UNHCR - UN High Commissioner for Refugees. http://www. unhcr.org/509136ca9.pdf

UNHCR - UN High Commissioner for Refugees. (2012b). Working with men and boy survivors of sexual and gender-based violence in forced displacement. UNHCR - UN High Commissioner for Refugees. https://www.refworld.org/docid/5006aa262.html

UNHCR - UN High Commissioner for Refugees. (2019). Desperate Journeys. Refugees and migrants arriving in Europe and at Europe's borders (January-December 2018). UNHCR. https://www.unhcr.org/desperatejourneys

United Nations Support Mission in Libya-Office of the High Commissioner for Human Rights. (2018). Desperate and dangerous: Report on the human rights situation of migrants and refugees in Libya. UN. https://www.ohchr.org/Documents/Countries/LY/LibyaMigrationReport.pdf

Winton, A. (2019). I've got to go somewhere': Queer displacement in Northern Central America and Southern Mexico. In A. Güler, M. Shevtsova, \& D. Venturi (Eds.), LGBTI asylum seekers and refugees from a legal and political perspective (pp. 95-116). Cham: Springer.

Open Access This chapter is licensed under the terms of the Creative Commons Attribution 4.0 International License (http://creativecommons.org/licenses/by/4.0/), which permits use, sharing, adaptation, distribution and reproduction in any medium or format, as long as you give appropriate credit to the original author(s) and the source, provide a link to the Creative Commons license and indicate if changes were made.

The images or other third party material in this chapter are included in the chapter's Creative Commons license, unless indicated otherwise in a credit line to the material. If material is not included in the chapter's Creative Commons license and your intended use is not permitted by statutory regulation or exceeds the permitted use, you will need to obtain permission directly from the copyright holder. 